\title{
LA PROTECCIÓN DE LAS AGUAS FRENTE A LA CONTAMINACIÓN Y OTROS ASPECTOS MEDIO- AMBIENTALES EN EL DERECHO ROMANO Y EN EL DERECHO CASTELLANO MEDIEVAL ${ }^{*}$
}

["Water Protection Against Pollution and Other Environmental Aspects in the Roman Law and in the Medieval Castilian Law"]

\author{
Patricia Zambrana Moral ${ }^{* *}$ \\ Universidad de Málaga
}

\begin{abstract}
Resumen
Este artículo tiene por objeto analizar, desde el punto de vista del Derecho histórico español, la tutela jurídica de uno de los elementos que integran el concepto de medio ambiente tal y como lo concebimos hoy en día. Así, nos ocupamos de las normas concretas dirigidas a proteger de manera directa o tangencial las aguas y a evitar su contaminación aunque también repasamos otras disposiciones con incidencia medioambiental. Entre los antecedentes, nos remontamos al llamado
\end{abstract}

\begin{abstract}
This article is aimed at analyzing, from the Spanish historical Law viewpoint, the legal protection of one of the elements constituting the concept of environment as we conceive it nowadays. Thus, we will address detailed rules aimed at directly or indirectly protecting the waters and to preventing them from being polluted. We also revise other stipulations that have environmental consequences. We trace them back to the so called "Code of Hammurabi”, where the first rules related
\end{abstract}

* El presente trabajo ha sido realizado en el seno de los proyectos: Derecho Europeo uniforme de contratos maritimos: Fundamentos históricos. Implicaciones medioambientales y económicas (P09-SEJ-4827. Proyecto de Excelencia de la Junta de Andalucía); Acción urbanizadora y Derecho urbanistico romano: ordenación del territorio, urbanismo, vivienda y medio ambiente (P08-SEJ-3923. Proyecto de Excelencia de la Junta de Andalucía) y Espacio único de sistemas de información ontológica y tesauros sobre el medio ambiente: ecoturismo (FFI2008-06080-C03-03. Proyecto I+D del Ministerio de Ciencia y Tecnología).

** Profesora titular de Historia del Derecho y de las Instituciones de la Facultad de Derecho de la Universidad de Málaga. Dirección postal: Boulevard Louis Pasteur, $n^{\circ} 24$, Campus de Teatinos, 29071 Málaga, España. Correo electrónico: pzambrana@uma.es 
"Código de Hammurabi", en donde se encuentran los primeros preceptos relacionados con la defensa jurídica del medio ambiente y después nos detenemos en el Derecho Romano. Asimismo, referimos el Derecho hispano-musulmán, partiendo de la trascendencia que otorgaban los musulmanes al agua desde el punto de vista espiritual y jurídico. Finalmente, nos centramos en el Derecho visigodo y en el Derecho castellano medieval a través de una selección de fueros y de la obra legislativa de Alfonso X (Espéculo, Fuero Real y Partidas).

Palabras Clave

Aguas - Medio Ambiente - Contaminación - Historia del Derecho ambiental - Código de Hammurabi. to the legal defense of the environment are set-forth and then we focus on the Roman Law. Likewise, we refer to the Spanish-Islamic Law, beginning from the transcendence the Muslims granted to the water from the spiritual and legal point of view. We finally focus on the Visigothic Code and on the Castilian Medieval Law by way of a selection of fueros and of the legislative work of Alfonso X (Especulo, Fuero Real and Partidas).

\section{KEYWORDS}

Water - Environment - Pollution History of Environmental Law - Code of Hammurabi.

[RECIBIDO el 15 de noviembre y ACEPTADo el 16 de diciembre de 2011].

\section{INTRODUCCIÓN}

Con carácter general, y sin entrar en definiciones concretas, el medio ambiente sería todo aquello que nos rodea y estaría integrado por un conjunto variado de elementos y fenómenos: aire, suelo, fauna, flora, elementos culturales, etc. $y$, por supuesto, agua ${ }^{1}$. Se trata de una materia interdisciplinaria que se mueve

${ }^{1}$ De un concepto estricto de medio ambiente, reducido a lo "meramente físico", frente a un concepto amplio que abarcaría también elementos culturales, nos hablan: FERNÁNdez Gimeno, José Pascual - Gamborino Martínez, Gloria, en Reyes López, María José (coordinadora), Derecho ambiental español (Valencia, Tirant lo Blanch, 2001), pp. 29-32. Ambos conceptos son referidos por Francesca Llodrà Grimalt, a la hora de delimitar el contenido del Derecho ambiental, afirmando que desde una "óptica restrictiva", "el objeto del Derecho ambiental consistiría en controlar las perturbaciones que en el medio ambiente producen las contaminaciones"; mientras que el concepto amplio "identifica el medio ambiente con un objeto amplísimo equivalente al conjunto de elementos físicos, psíquicos y sociales que condicionan la vida del ser humano", es decir, "el conjunto de circunstancias físicas, culturales, económicas y sociales que rodean a una persona” [LLODRÀ Grimalt, Francesca, Lecciones de Derecho ambiental civil (Palma, Universitat de les Illes Balears, 2008), p. 17]. A la dificultad de delimitar el contenido del medio ambiente y de concretar un concepto jurídico, aludía Gómez Rojo, María Encarnación, Precedentes de protección medioambiental en el Derecho Histórico Español de la Edad Moderna, en ARANCibia MATtAR, Jaime - MARTínez Estay, José Ignacio (coordinadores), La primacía 
entre el Derecho público y el privado, aunque, históricamente, se ubicaba más bien en este último (sobre todo Derecho civil), tratando de proteger intereses y derechos particulares (básicamente el derecho de propiedad), más que colectivos ${ }^{2}$. El Derecho del medio ambiente o Derecho ambiental, tal y como lo entendemos hoy en día, surge en épocas muy recientes, hasta el punto de que el primer texto de carácter internacional que analiza la problemática medioambiental y trata de darle respuesta es la famosa "Declaración de Estocolmo" de $1972^{3}$. Por su misma interdisciplinariedad, en la protección del medio ambiente se implican actualmente diferentes ramas del Derecho: civil $^{4}$, administrativo ${ }^{5}$, penal ${ }^{6}$, cons-

de la persona. Estudios en homenaje al Profesor Eduardo Soto Kloss (Santiago de Chile, LegalPublishing, AbeledoPerrot, 2009), pp. 641-642. De lo que no hay duda alguna, con independencia del concepto que se maneje, es de que el agua es un elemento integrante del medio ambiente.

${ }^{2}$ Se señala que, "aunque el desarrollo del Derecho ambiental está gobernado por el aspecto público y administrativo del mismo", sería el Derecho privado el que dio "las primeras soluciones a los problemas ambientales" y el "Derecho civil siempre ha estado presente en la temática medioambiental", sobre todo en el Derecho romano y en el Derecho histórico español [Llodrà Grimalt, Francesca, cit. (n. 1), p. 21]. Cfr. Gómez Rojo, María Encarnación, cit. (n. 1), p. 642. Fernández Gimeno y Gamborino Martínez insisten en esta misma idea, pero indican que "junto a los intereses privados aparecía en ocasiones el interés público y el supraindividual, aunque siempre restringido al ámbito higiénico sanitario o estético" [Fernández Gimeno, José Pascual y GAMBORINo MARTíneZ, Gloria, cit. (n. 1), p. 12]. Una opinión similar sostiene JorDANO FRAGA, Jesús, La protección del derecho a un medio ambiente adecuado (Barcelona, Bosch, 1995), pp. 18-19.

${ }^{3}$ Declaración de la Conferencia de las Naciones Unidas sobre el Medio Ambiente humano de Estocolmo (5-16 de junio de 1972). Aquí se define el medio ambiente como "el conjunto de componentes físicos, químicos, biológicos y sociales capaces de causar efectos directos o indirectos, en un plazo corto o largo, sobre los seres vivos y las actividades humanas".

${ }^{4}$ Aparte del referido trabajo de Llodrà Grimalt, Francesca, cit. (n. 1), se puede consultar también LuQuín BERGARECHE, Raquel, Mecanismos jurídicos civiles de tutela ambiental (Navarra, Aranzadi, 2005). Se ofrece un concepto de ambiente amplio desde el punto de vista civil.

${ }^{5}$ Cfr. Roca Roca, Eduardo, La contaminación de las aguas públicas (sus problemas y régimen juridico administrativo), en Revista General del Derecho, 336, 337-338 (octubre-noviembre 1972), 28 pp. de la separata; Lozano Cutanda, Blanca, Derecho ambiental administrativo (9a edición, Madrid, Dykinson, 2008; $11^{\text {a }}$ edición, Madrid, La Ley, 2010); y Lozano Cutanda, Blanca - Alli Turrillas, Juan Cruz, Administración y legislación ambiental ( $5^{\text {a }}$ edición, Madrid, Dykinson, 2009).

${ }^{6}$ Cancio Meliá, Manuel - Jorge Barreiro, Agustín (coordinadores), Estudios sobre la protección penal del medio ambiente en el ordenamiento jurídico español (Granada, Comares, 2005); Cantero Cereuella, Cristóbal Javier, La responsabilidad penal de los funcionarios por delitos ambientales (con "Prólogo" de Agustín Jorge Barreiro y Manuel Cancio Meliá, Madrid, Reus, 2010); Mendo Estrella, Álvaro, El delito ecológico del artículo 325.1 del Código Penal (Valencia, Tirant lo Blanc, 2009); 
titucional $^{7} \mathrm{o}$ internacional ${ }^{8}$.

Desde los primeros tiempos, el hombre ha utilizado y ha tratado de dominar el medio que le rodeaba y esta lucha constante ha tenido como consecuencias continuas agresiones y un deterioro progresivo del mismo, poniendo en peligro su existencia ${ }^{9}$. El desarrollo de los núcleos urbanos será determinante a la hora de establecer ciertos límites en el uso (hasta entonces indiscriminado) de los elementos naturales y del propio entorno. Será sobre todo a partir de ese momento cuando se empiece a sentir la necesidad de que el Derecho intervenga para solucionar conflictos derivados de la concentración de personas en las ciudades (por ejemplo, el problema de los residuos) ${ }^{10}$.

El menoscabo del medio ambiente a lo largo de la historia es obvio; no obstante, lo que aquí nos interesa no es constatar aquél sino analizar, desde

Matellanes Rodríguez, Nuria, Derecho penal del medio ambiente (Madrid, Iustel, 2008); Martos Nuñez, Juan Antonio [et alii], Derecho penal ambiental (Madrid, Exlibris, 2006) y Martos Nuñez, Juan Antonio, El delito de contaminación acústica (Madrid, Iustel, 2010).

${ }^{7}$ Escobar Roca, Guillermo, La ordenación constitucional del medio ambiente (Madrid, Dykinson, 1995); y Canosa Usera, Raúl, Constitución y medio ambiente (Madrid, Dykinson, 2000).

${ }^{8}$ Véanse: BALlENEGGER, Jacques, La pollution en droit international: la responsabilité pour les dommages causés par la pollution transfrontière (Lausanne, Imprimerie Vaudoise, 1975); Springer, Allen L., The International Law of Pollution (WesportLondon, Quórum Books, 1983); KIss, Alexandre, Droit international de l'environnement (Paris, Pedone, 1989); Kiss, Alexandre - Shelton, Dinah, A Guide to International Environmental Law (Leiden-Boston, Martinus Nijhoff publishers, 2007). En materia de aguas fluviales y con perspectiva internacional, se puede consultar el trabajo de Ponte Iglesias, María Teresa, La contaminación fluvial: cuestiones de responsabilidad internacional (Santiago de Compostela, Xunta de Galicia, Consellería da Presidencia e Administración Pública, Servicio Central de Publicacions, 1989). En el ámbito de la Unión Europea, véanse: KIss, Alexandre - Shelton, Dinah, Manual of European Environmental Law (2a edición, Cambridge, Grotius, 1997); KRÄMER, Ludwig, Derecho ambiental y Tratado de la Comunidad Europea (traducción de la $3^{\text {a }}$ edición de Luciano Parejo Alfonso y Ángel Manuel Moreno Molina, Madrid, Marcial Pons, 1999); García Ureta, Agustín (coordinadores), Estudios de Derecho ambiental europeo (Bilbao-Pamplona, ed. Pamiela, 2006); Moreno Molina, Ángel Manuel, Derecho comunitario del medio ambiente, marco institucional, regulación sectorial y aplicación en España (Madrid, Marcial Pons, 2006); Vercher Noguera, Antonio, El derecho europeo medioambiental (Madrid, Consejo General del Poder Judicial, 2005); y El mismo, El derecho europeo medioambiental: la protección del medio ambiente en la Unión Europea. Aspectos críticos (Madrid, Consejo General del Poder Judicial, 2008).

${ }^{9} \mathrm{Cfr}$. Federovisky, Sergio, Historia del medio ambiente (Buenos Aires, editorial Capital Intelectual, 2007); y GonZÁLEZ DE Molina, Manuel, Historia y medio ambiente (Madrid, Eudema, 1993).

${ }^{10}$ Véase Jordano Fraga, Jesús, cit. (n. 2), p. 17. 
el punto de vista del Derecho histórico español, la tutela jurídica de uno de sus elementos. Así, nos ocupamos de las normas concretas dirigidas a proteger de manera directa o tangencial las aguas y a evitar su contaminación ${ }^{11}$, aunque también repasamos, sin entrar en detalle, otras disposiciones con incidencia medioambiental.

Aunque se indica que la protección jurídica del hábitat en el mundo occidental es muy reciente, descubrimos en el Derecho histórico normas con tal finalidad, partiendo siempre de concepciones actuales ${ }^{12}$, es decir, preceptos que, en cierta medida, van dirigidos a evitar daños en los elementos que integran el medio ambiente, tal y como lo concebimos hoy en día, y concretamente en uno de dichos elementos (el agua $)^{13}$. Pese a que la magnitud del problema de la contaminación no es comparable con la actualidad, sería un error pensar en su inexistencia en el mundo antiguo ${ }^{14}$.

Al parecer, los precursores en la tutela medioambiental fueron los pueblos orientales. Encontramos algunas disposiciones al respecto en el llamado

${ }^{11}$ Siguiendo un concepto actual, según el art. 93 del Real Decreto Legislativo $\mathrm{N}^{\circ}$ 1/2001, de 20 de julio, por el que se aprueba el texto refundido de la Ley de aguas, en su redacción dada por la Ley $\mathrm{N}^{\circ} 62 / 2003$, de 30 de diciembre, "se entiende por contaminación, a los efectos de esta Ley, la acción y el efecto de introducir materias oformas de energía, o inducir condiciones en el agua que, de modo directo o indirecto impliquen una alteración perjudicial de su calidad en relación con los usos posteriores, con la salud humana, o con los ecosistemas acuáticos o terrestres directamente asociados a los acuáticos; causen daños a los bienes; y deterioren o dificulten el disfrute y los usos del medio ambiente".

${ }^{12}$ Insistimos en que vamos a partir de lo que se entiende hoy en día por medio ambiente y por contaminación y que antes referíamos. Históricamente, no se puede hablar de un Derecho ambiental sino que las normas que recogemos y que, desde una perspectiva actual, nos parecen claramente medioambientales se ubicaban en otros sectores del ordenamiento jurídico (ordenación del territorio, urbanismo, sanidad, propiedad, servidumbre, relaciones de vecindadm [...]) o bien obedecían a diferentes motivaciones e incluso a intereses económicos. Cfr. Jordano FraGa, Jesús, cit. (n. 2), pp. 16 y 22.

${ }^{13}$ Son pocos los trabajos sobre esta materia y, como afirma Gabriel M. Gerez Kraemer no es de extrañar, ya que en nuestro propio ordenamiento, y hasta la Ley de 1866, las aguas no tienen una normativa específica y autónoma a pesar de su importancia [Gerez Kraemer, Gabriel M., El derecho de aguas en Roma (Madrid, Dykinson, 2008), p. 18. Se trata de un interesante trabajo en torno a la cuestión pero con escasa incidencia en el tema de la contaminación].

${ }^{14}$ Entre los griegos se refiere la historia de Heracles como el primer caso que revela una conciencia del problema ecológico [FEDELI, Paolo, La natura violata. Ecologia e mondo romano (Palermo, Sellerio, 1990), p. 66]. 
"Código de Hammurabi" ${ }^{15}$, pero son escasas las relacionadas con las aguas ${ }^{16} \mathrm{y}$

${ }^{15}$ Dareste de la Chavanne, Rodolphe, Le Code babylonien d'Hammourabi, en Nouvelle Revue Historique de Droit Français et Étranger, 27 (1903), pp. 5-34 ; y en Nouvelles études d'histoire du droit (Paris, Librairie de la Société du Recueil J.-B. Sirey $\&$ du Journal du Palais. Ancienne Maison L. Larose \& Forcel, 1906), pp. 1-40. Se suele indicar que el antecedente histórico más antiguo relacionado con la defensa jurídica del medio ambiente lo encontramos en este cuerpo legal donde se protegían los animales, prohibiéndose la sobreexplotación o la utilización indebida o negligente de los mismos. Así, el que alquilaba un buey y, por negligencia, le causaba la muerte o le rompía un casco o le cortaba el tendón del cuello (lo que lo hacía inservible para el trabajo) debía pagar, en concepto de multa, al propietario del buey, un buey equivalente ["Código de Hammurabi”, $\$ \$ 245$ y 246, edición de Lara Peinado, Federico (Madrid, 1982), pp. 118 y 252, nota 592]. Si el que arrendaba un buey, le destruía un ojo tenía que abonar al propietario la mitad de su precio, y la cuarta parte si le rompía un asta, le cortaba la cola o le dañaba la espalda ["Código de Hammurabi”, $\$ \$ 247$ y 248, edición de LARA Peinado, Federico, cit., p. 118]. El que robaba cereales y con ello perjudicaba a los animales debilitándolos, tenía que devolver el doble del grano robado ["Código de Hammurabi”, \$254, edición de LaRa Peinado, Federico, cit., p. 119]. La "Ley del Talión” más estricta se aplicaba al que dejaba perecer al buey o al cordero que le había sido confiado (buey por buey y cordero por cordero) [“Código de Hammurabi”, \$263, edición de Lara Peinado, Federico, cit., p. 119]. Por su parte, el pastor al que se le confiaba ganado para apacentarlo y dejaba disminuir el ganado mayor o menor, habiendo cobrado ya por dicho trabajo, debía entregar las crías y los beneficios ["Código de Hammurabi”, \264, edición de Lara Peinado, Federico, cit., pp. 119-120]. Asimismo, el pastor que, por negligencia, permitía que se propagase la sarna o cualquier infección en el rebaño tenía que restituir el ganado perdido [“Código de Hammurabi”, $\$ 267$, edición de Lara Peinado, Federico, cit., pp. 120 y 257-258, nota 632]. Véase Éxodo 21, 37 y 22, 13-14. Véase la comparación entre el Éxodo y el "Código de Hammurabi" de Boscheron, Achille, Babylone et la Bible. Code de Hammourabi et Livre de L'Alliance (Caen, Imprimerie Charles Valin, 1906), pp. 27-31. Sin embargo, resulta obvio que estas disposiciones iban dirigidas a proteger la propiedad o a los animales como instrumentos de trabajo para la agricultura, más que a la especie o en sí mismos como elementos del medio ambiente. Cfr. Ja uenenod Martínez, Silvia Susana, El Derecho ambiental y sus principios rectores (Madrid, Universidad Complutense, 1989), p. 71. En el Liber Iudiciorum, en el Fuero Juzgo, en muchos de nuestros fueros medievales y en el Fuero Real se contienen normas similares. No apreciamos preocupación medioambiental en "Código de Hammurabi", $\$ 25$ [edición de LaRa Peinado, Federico, cit., p. 94] donde se contempla el robo con ocasión de un incendio fortuito. En cuanto a la quema de "mieses", vid. Éxodo 22, 5 y sobre el incendio, en general, Coll. 12 [Mosaicorum et Romanorum legum collatio (traducción, introducción e índice de palabras anotado por Montemayor Aceves, Martha Elena (México, Universidad Nacional Autónoma de México, 1994), pp. 34-38].

${ }^{16}$ Precisa Lara Peinado que "llama la atención la poca importancia dedicada (en el "Código de Hammurabi") a las construcciones e instalaciones de riegos", que fueron "indispensables para la civilización mesopotámica". Supone que de esta cuestión se ocuparía el Derecho consuetudinario [Lara Peinado, Federico, cit. (n. 15), p. 66]. 
ninguna con la contaminación de las mismas. Sí que aparecen normas relativas a los daños ocasionados por el agua en las tierras de labranza, próximas al Derecho penal ${ }^{17}$. La negligencia a la hora de reforzar un dique que provocaba una fuga de agua que devastaba las tierras del vecino obligaba al responsable a compensar el grano perdido ${ }^{18}$. En caso de insolvencia, es decir, si el culpable no podía pagar el grano, la pena subsidiaria era personal: era vendido junto con sus bienes y el importe de la venta se repartía entre los ocupantes de las tierras dañadas ${ }^{19}$. Asimismo, el que abría una alberca para la irrigación de forma negligente permitiendo que las aguas destruyesen el fundo vecino debía reparar el daño ocasionado a la cosecha ${ }^{20}$.

La "red de acequias y canales derivados a partir del Éufrates y Tigris” permitiría la prosperidad de la agricultura al tratarse de una zona de escasas lluvias. No obstante, como consecuencia negativa se produciría una progresiva salinización del suelo [LARA PEINADO, Federico, cit. (n. 15), pp. 187-188, nota 214].

${ }^{17}$ De delitos relativos al uso de canales y problemas hidráulicos, habla Lara Peinado, pero advierte que no hay ninguna "alusión al castigo que podría originarse por robar el agua para el riego", recurriéndose, en estos casos, a las normas consuetudinarias [LARA Peinado, Federico, cit. (n. 15), pp. 188-189, nota 223]. En concreto, son cuatro los artículos del "Código de Hammurabi" que regulan la irrigación de los campos ( $\$ 53$ 56). Estos preceptos los comenta Manlio Sargenti al analizar el régimen jurídico del agua en los Derechos mediterráneos. Señala que este cuerpo legal tiene como presupuesto, a la hora de sancionar, la negligencia o la culpa del propietario del fundo del que procede el daño y la acción prevista para varios casos de perjuicios ocasionados por el agua es una acción de resarcimiento que se mide por el daño producido y que solo en caso de insolvencia vendría sustituida por una "expropiación" general de los bienes y de la misma persona, seguida de la venta destinada a dar satisfacción a las demandas de los perjudicados [SARgenti, Manlio, L'actio aquae pluviae arcendae. Contributo alla dottrina della responsabilità per danno nel diritto romano (Milano, Giuffrè, 1940), pp. 15-16]. Cfr. Boscheron, Achille, cit. (n. 15), pp. 61-62.

18 "Código de Hammurabi", $₫ 53$, edición de Lara Peinado, Federico, cit. (n. 15), p. 97.

19 "Código de Hammurabi”, $\$ 54$, edición de Lara Peinado, Federico, cit. (n. 15), p. 98.

20 "Código de Hammurabi", $\$ 55$, edición de Lara Peinado, Federico, cit. (n. 15), p. 98. En sentido similar, "Código de Hammurabi”, \$ 56. Según Lara Peinado, la diferencia entre ambos artículos es que en el $\$ 55$ "la inundación se había producido durante la siega" y "la indemnización se evaluaba de acuerdo con la producción del campo". Por su parte, en el $\$ 56$ nos encontramos con un campo preparado para la producción y la indemnización se establecía según la extensión del mismo, "a razón de algo más de 190 litros de grano por hectárea, sin entrar en la mayor o menor productividad de las tierras" [Lara Peinado, Federico, cit. (n. 15), p. 188, nota 223]. 


\section{DERECHO ROMANO}

Teniendo en cuenta el indudable interés del Derecho romano por la protección del entorno y, en consecuencia, por lo que hoy entendemos como medio ambiente, se hace necesario recoger algunas disposiciones y algún estudio sobre la materia que nos permitan articular el presente trabajo y situar los antecedentes del Derecho histórico español ${ }^{21}$.

$\mathrm{Al}$ margen de las aguas y por referir las primeras normas del Derecho romano de carácter medioambiental, en la Ley de las XII Tablas no se permitía enterrar ni incinerar un cadáver humano dentro la ciudad ${ }^{22}$. Cicerón especificaba aun más prohibiendo la incineración de personas o situar una tumba en un radio de 60 pies de una casa ajena, contra la voluntad de su dueño (entendemos que se admitiría con el consentimiento del propietario de la vivienda en cuestión ${ }^{23}$. Evidentemente, esta normativa tenía como fi-

${ }^{21}$ Sobre el tema específico de las aguas, aparte del trabajo de Gerez KraEmer, Gabriel M., cit. (n. 13), podemos referir los de AlLARD, Georges, Législation romaine sur les eaux (tesis doctoral, Lille, Imprimerie L. Danel, 1874), pp. 5-72; CosTA, Emilio, Le acque nel Diritto romano (Bologna, Nicola Zanichelli editore, 1919) o los más recientes de Gómez Royo, Enrique, El régimen de las aguas en las relaciones de vecindad en Roma (Valencia, Tirant lo Blanch, 1997); y García Quintas, María de las Mercedes, Algunas implicaciones jurídicas de la conducción del agua a la Roma Antigua, en Anuario Jurídico y Económico Escurialense, 44 (2011), pp. 49-72. Ninguno plantea la cuestión ambiental. Por el contrario, Zamora Manzano, José Luis, Precedentes romanos sobre el Derecho ambiental. La contaminación de las aguas, canalización de las aguas fecales y la tala ilícita forestal (Madrid, Edisofer, 2003), pp. 19-67, dedica un capítulo completo al estudio de la contaminación de las aguas en el Derecho romano. Sin entrar en aspectos jurídicos, sí que incide en el medio ambiente la obra de Fedeli, Paolo, cit. (n. 14).

${ }^{22}$ Tab. X,1: "Hominem mortuum in urbe ne sepelito neve urito". Transcribimos el texto de la Tabla X,1 tal y como se recoge en las ediciones consultadas de BRUNS, K. G., Fontes iuris romani antiqui ( $7^{\mathrm{a}}$ edición, Tübingen, 1909, reedición, Scientia Verlag Aalen, 1969), p. 35; Ricсовоno, Salvatore, Fontes Iuris Romani Antejustiniani, Pars Prima, Leges (Firenze, Barbèra, 1968), p. 66; y Rascón García, César - García GonZález, José María, Ley de las XII Tablas (Madrid, Tecnos, 1993), pp. 30-31, que habitualmente se transcriben con mayúsculas para hacer correspondencia con lo que la doctrina cree haber sido texto original, aunque aquí no hemos seguido esa costumbre. Véase también la edición coordinada por Domingo, Rafael, Textos de Derecho romano (Cizur Menor, Aranzadi, 2002), p. 33 (aquí se opta por la negrita para transcribir lo que sería cita textual). Apuntaba San Isidoro que, en un principio, los muertos eran enterrados en sus propias casas, pero con el paso del tiempo esto fue prohibido por las leyes para evitar el hedor y las infecciones por el contacto de los que habitaban dicha casa [SAN Isidoro, Etymologiarum, XV, 11, 1 (edición bilingüe de OrOz, J. y Marcos, M. A., 2a edición, Madrid, Biblioteca de autores cristianos, 1994), II, pp. 250-251].

${ }^{23}$ Tab. X,9 [edición de Bruns, K. G., cit. (n. 22), p. 37; edición de Riccobono, Salvatore, cit. (n. 22), p. 69; edición de Rascón García, César - García GonZá- 
nalidad proteger la salud pública y mantener la higiene en las ciudades lo que, desde una óptica actual, tendría claras implicaciones medioambientales ${ }^{24}$. En relación a las aguas, solo cabe aludir la referencia a los daños causados por el agua de lluvia ${ }^{25}$ y la concesión de acción a favor de aquel particular que se veía perjudicado en su fundo por un caudal de agua (río o acueducto) que era conducido por un terreno público para que fuese indemnizado por el daño ${ }^{26}$.

LEZ, José María, cit. (n. 22), pp. 32-33 y 35 y edición coordinada por Domingo, Rafael, cit. (n. 22), p. 34]. Rascón y García traducen el término bustum que aparece en la norma como tumba ("prohíbe [la Ley de las XII Tablas] instalar un lugar de incineración o una tumba nuevos [...]") con el fin de "hacer posible una interpretación amplia del precepto" y siguiendo la "conocida explicación de Festo (F. 84) de que, si bien bustum significa el lugar en el que se quema al muerto y se entierran sus cenizas [...], "a veces llamamos busta a los sepulchra”“ “ [RAscón GARCía, César y GARCía GonZÁLEZ, José María, cit. (n. 22), p. 96]. Sin embargo, en la edición coordinada por Rafael Domingo se traduce de forma literal: "prohíbe acercar la pira funeraria o el nuevo lugar de incineración [...]" [Domingo, Rafael, cit. (n. 22), p. 34]. En una interpretación estricta, el propio Cicerón (de legibus 2,24,61) indicaba que la finalidad de la disposición, al parecer, era evitar el incendio [Cicerón, Marco Tulio, Las leyes (traducción, introducción y notas por Álvaro D’Ors, Madrid, Instituto de Estudios Políticos), 1970, pp. 184-185]. Entendemos que el matiz es fundamental sobre todo desde el punto de vista medioambiental ya que la prohibición podría obedecer solo a razones de seguridad por el peligro del fuego o también a razones higiénicas por lo que supone enterrar un cadáver cerca de una vivienda. Para Zamora Manzano, no solo se contempla aquí la "facultad de incinerar sino también la posibilidad de instalar un crematorio en los límites ordinarios del fundo propio que puede llegar a ser objeto de servidumbre si así lo decide el titular del terreno adyacente a menos distancia de los sesenta pies establecidos en la ley" [Zamora Manzano, José Luis, cit. (n. 21), p. 17].

${ }^{24}$ Según Cicerón (de legibus 2,23,58) la prohibición de la incineración de la Tab. $\mathrm{X}, 1$ no se basaba en motivos religiosos sino también de seguridad por el riesgo de incendios, es decir, por el peligro que suponía el fuego o incluso el humo derivado de la incineración. El añadido "ni se incinere" indicaría que "no se entierra el que se incinera, sino el que se inhuma” [Cicerón, Marco Tulio, cit. (n. 23), pp. 178-179]. Así, respecto a la inhumación, la interdicción obedecería a razones de higiene ya que va referida "al cadáver íntegro, permitiéndose, en cambio, inhumar los restos del previamente incinerado" [Rascón García, César y García González, José María, cit. (n. 22), pp. 93-94]. A nuestro entender, si el objetivo principal o único era evitar incendios, no tendría mucho sentido que en la Tab. X,1 se especificase "hominem mortuum", limitando la restricción al cadáver humano, ni que se tolerase la incineración sin respetar la distancia de seguridad con el permiso del propietario de la vivienda ajena o si se hacía cerca de una casa propia ya que existiría el mismo riesgo de incendio.

${ }^{25}$ Tab. VII,8a [edición de Bruns, K. G., cit. (n. 22), p. 27; edición de Riccobono, Salvatore, cit. (n. 22), p. 50; edición de Rascón García, César y García GonZáLEZ, José María, cit. (n. 22), pp. 18-19 y edición coordinada por Domingo, Rafael, cit. (n. 22), p. 28]. Cfr. D. 40,7,21 (Pomp., 7 ex Plaut.).

${ }^{26}$ Tab. VII,8b [edición de Bruns, K. G., cit. (n. 22), p. 27; edición de RiccoBono, Salvatore, cit. (n. 22), p. 50; edición de Rascón García, César y García 
No se recogía nada en materia de contaminación, aunque se reflejan las dos perspectivas con las que el agua ha sido considerada a lo largo de la historia: como causa de daños o como un bien susceptible de aprovechamiento ${ }^{27}$.

La primera disposición dirigida de forma tal vez más directa a preservar el medio ambiente con base en un interés general más que individua ${ }^{28}$ aparece en el Digesto y tiene como objeto, precisamente, la protección de las aguas. Se trata de un texto de las sentencias de Paulo que se sitúa en el título de extraordinariis criminibus en el que se recoge la palabra contaminaverit. No se contiene una prohibición expresa, ni una sanción concreta $^{29}$, sino que se considera injuria contra las buenas costumbres todo acto dirigido a echar estiércol o manchar a alguien con cieno o lodo o ensuciar las aguas, cañerías y lagos y, en general, contaminar en perjuicio público ${ }^{30}$.

GonZÁlez, José María, cit. (n. 22), pp. 18-19 y edición coordinada por Domingo, Rafael, cit. (n. 22), p. 28]. Sobre la relación "tradicional” entre la actio aquae pluviae arcendae y la servitus aquaeductus, en el sentido de que la servidumbre pueda convertir una intromisión de aguas en el fundo vecino en lícita, cfr. Gerez KraEmer, Gabriel M., cit. (n. 13), pp. 27-29.

${ }^{27}$ Expresa esta idea Gerez Kraemer, Gabriel M., cit. (n. 13), p. 19.

${ }^{28}$ Es importante insistir en la idea que manifestaba Jordano Fraga en la línea de que las normas de Derecho romano relativas a problemas ambientales se situaban, en su mayoría, en la "esfera de los intereses privados", por lo que los "mecanismos de reacción” estaban en manos de los particulares, consiguiéndose "la defensa del interés supraindividual del disfrute de las condiciones aptas del entorno vital" de una forma "refleja”. Además, el enfoque era represivo y se actuaba una vez producida la agresión, a diferencia del actual Derecho ambiental de carácter preventivo [JoRDANo FRAGA, Jesús, cit. (n. 2), pp. 19 y 22].

${ }^{29}$ Indica Zamora Manzano que la contaminación no aparece en este fragmento como una forma autónoma de ilícito penal, aunque, seguidamente, incurre en cierta contradicción ya que comparte la opinión de Balzarini al catalogar este hecho como delito ecológico, concepto que no existía en el Derecho romano [Zamora MANZANo, José Luis, cit. (n. 21), p. 20]. Para Jordano Fraga se trata de un delito que se podría considerar precedente del delito ecológico y estaría sometido a un castigo severo [JoRDANO FRAGA, Jesús, cit. (n. 2), p. 21].

${ }^{30}$ D. 47,11,1,1 (Paul., 5 sent.) [hemos consultado la edición del Digesto de МоммSen, Theodor - Krueger, Paul, Corpus Iuris Civilis (13 ${ }^{\text {a }}$ edición, Berlin, Apud Weidmannos, 1920), I]. Hay quien considera que en este texto el término lacus equivale a piscina y no a lago [Gerez Kraemer, Gabriel M., cit. (n. 13), p. 86, en nota]. Véase: Proudhon, M. Traitédu domaine public, ou de la distinction des biens considérés principalement par rapport au domaine public (Dijon, Victor Lagier, Libraire-Éditeur, 1834), IV, p. 329. También se observa la protección medioambiental con un fin higiénicosanitario de carácter público en D. 43,10,5 (Pap., lib. sing de off. aed.) donde se prohíbe expresamente dejar las basuras y los animales muertos o sus pieles en las calles y se encarga a los ediles que vigilen esta cuestión. Sobre este pasaje, véase PonTE, V. Régimen jurídico de las vías públicas en Derecho Romano (Madrid, Dykinson, 2007), p. 240. 
Hay quien señala que la preocupación de los romanos por la pureza del agua $^{31}$ y por "mantener la calidad y la salubridad de las aguas" supone todo "un sistema de postulados ambientales" en la materia ${ }^{32}$. Así, encontramos un fragmento del Digesto donde se contempla la contaminación de las aguas del fundo vecino por "instalación de sistemas hidráulicos para uso industrial de lavanderías" o lavaderos de tintorería (fullonicae) junto a una fuente en el fundo propio, es decir, utilizar una corriente de agua de forma que pueda perjudicar a otros por conducir a sus tierras agua sucia ${ }^{33}$. El supuesto de hecho es el de un propietario que instala en su fundo unos lavaderos junto a una fuente y esto ocasiona una inmisión de agua en el fundo vecino. Lo que se plantea es la posibilidad de utilizar la actio aquae pluviae arcendae concebida

${ }^{31}$ Afirma Paolo Fedeli que, incluso en ausencia de fenómenos de contaminación de las aguas comparables a los modernos, los ejemplos que aparecen en la legislación romana sobre la materia, manifiestan una constante preocupación por preservar su pureza. Expone los consejos de Vitruvio para evitar la impureza del agua y garantizar su calidad y alude a las ideas de éste acerca de la relación entre la salubridad del agua y la constitución física y el aspecto saludable de los que la beben, haciéndose eco de un claro determinismo ambiental. En cualquier caso, la protección del agua guarda conexión con las propiedades curativas que se le atribuyen, con su importancia para la salud y la fertilidad y, sin duda, con el elemento religioso y el culto a la divinidad [FedeLI, Paolo, cit. (n. 14), pp. 60-63]. Sobre las propiedades generales del agua que reflejan la referida importancia del líquido elemento, véase SAN IsIdoro, Etymologiarum, XIII, 12, 4, edición bilingüe de Oroz, J. y Marcos, M. A., cit. (n. 22), II, pp. 140-141.

${ }^{32}$ Zamora Manzano, José Luis, cit. (n. 21), p. 21.

${ }^{33}$ Se trata una cita que Ulpiano hace de Trebacio, recogida en D. 39,3,3, pr. (Ulp., 53 ad ed.). Gerez Kraemer considera este pasaje indispensable para delimitar el concepto de agua pluvial y de fuente [Gerez Kraemer, Gabriel M., cit. (n. 13), pp. 29, 58, 64 y 230]. El texto es examinado con detalle por Zamora Manzano, desde el punto de vista ambiental, planteando los aspectos procesales y las posibles acciones, aunque indica, de forma errónea, que se trata de un "fragmento de Ulpiano, lib. III ad Edictum" cuando en realidad es del libro 53 [Zamora MANZano, José Luis, cit. (n. 21), pp. 2129]. Justo García Sánchez alude a su difícil comprensión y a las diversas interpretaciones [García Sánchez, Justo, Teoría de la immissio (Madrid, 1975; 1ª reimpresión, Oviedo, 1979; $2^{\text {a }}$ reimpresión, Oviedo, Servicio de Publicaciones de la Universidad de Oviedo, 1999), pp. 22 y 118-122]. Véase también el análisis que hace de este pasaje: Gómez Royo, Enrique, cit. (n. 21), pp. 88-91; Jiménez Salcedo, Ma Carmen, El régimen jurídico de las relaciones de vecindad en Derecho romano (con "Prólogo" de Antonio Fernández de Buján, Córdoba, publicaciones de la Universidad de Córdoba y Obra Social y Cultural Cajasur, 1999), pp. 97-100; Di PorTo, Andrea, La tutela della "salubritas" fra editto e giurisprudenza, I: Il ruolo di Labeone (Milano, Giuffrè, 1990), pp. 56-84 o los comentarios más clásicos de Bonfante, Pietro, Las relaciones de vecindad (traducción, "prólogo", concordancias y apéndice de Alfonso García Valdecasas, Madrid, Reus, 1932), pp. 36-37; SARgenti, Manlio, cit. (n. 17), pp. 33-39 o Sitzia, Francesco, Ricerche in tema di "actio aquae pluviae arcendae". Dalle XII Tavole all'epoca classica (Milano, Giuffrè, 1977), pp. 156-163. 
en sentido amplio, esto es, no limitada al agua de lluvia ${ }^{34}$. Contra la simple inmisión no cabría dicha acción ${ }^{35}$, pero sí que se podría impedir que el agua

${ }^{34}$ En general, sobre la actio aquae pluviae arcendae, cuyo fin último es restituir las cosas a su estado inicial, se pueden consultar: Delzons, Hector, De aqua et aquae pluviae arcendae (tesis de licenciatura, Paris, Imprimerie de A. Henry, 1844); BIONDI, Biondo, Istituzioni di diritto romano (Milano, Giuffrè, 1946), pp. 192-193; BonfanTE, Pietro, Istituzioni di diritto romano (10 a edición, Torino, Giappichelli, 1946), pp. 307-310 o Iglesias, Juan, Derecho romano (17 a edición, Barcelona, Ariel, 2008), p. 163. El concepto, características y requisitos los sintetiza Jiménez SALCEdo, Ma Carmen, cit. (n. 33), pp. 203-215. Un completo estudio de la acción nos lo ofrecen Manlio Sargenti, Francesco Sitzia o Enrique Gómez Royo en las obras citadas en la nota anterior. En cuanto a la posibilidad del ejercicio de esta acción en relación con otros pasajes del Digesto, en los que no vamos a entrar por apartarse del tema de la contaminación, véase GARCía SÁNCHEZ, Justo, cit. (n. 33), pp. 162-178. El principio básico es que "no es lícito a una persona cambiar la condición normal del propio fundo para aumentar o disminuir el curso del agua de lluvia en perjuicio del vecino". Esta condición normal podría consistir en la cualidad natural del terreno o bien en construcciones artificiales, fosos, diques, presas, zanjas, etc. legalmente construidos. Si la construcción era ilegal se podría solicitar su destrucción [Bussi, Emilio, La formazione dei dogmi di diritto privato nel diritto comune. Diritti reali e diritti di obbligazione (Padova, Cedam, 1937), p. 79]. Véase: D. 39,3, 1,1 (Ulp., 53 ad ed.).

${ }^{35}$ No podemos obviar que la immissio es "el eje central sobre el que giran las relaciones de vecindad” y, en principio, ningún propietario debe soportar una inmisión en su "esfera jurídica dominical" aunque hay inmisiones que, "por su mínimo grado de intensidad o por la forma en que se producen, no suponen un grave perjuicio para el que las padece" y "el Derecho impone el deber de tolerarlas" [Jiménez SALCEdo, Ma Carmen, cit. (n. 33), p. 35]. Así, Zamora Manzano considera que Trebacio niega la actio aquae pluviae arcendae para la simple inmisión de aguas ocasionada por la instalación de los lavaderos que debe ser tolerada por el vecino por tratarse de "inmisiones derivadas de una necesidad ineludible en el ejercicio de un derecho", es decir, una inmisión mínima necesaria [Zamora ManZano, José Luis, cit. (n. 21), pp. 22 y 28]. En este punto, no aporta nada nuevo sino que sigue la opinión de García Sánchez quien, tras analizar las diferentes interpretaciones doctrinales, concluye que la referida inmisión "deriva del curso normal de la fuente” y no hay posibilidad de impedirla por ser lícita. Se trata de la teoría del uso normal que permitiría "inmisiones mínimas, en cuanto necesarias para el uso normal del fundo, a fin de que el derecho del propietario no se vea privado, en gran parte, de muchas facultades que en teoría le corresponden iure dominio" [GARCíA SÁnCHEZ, Justo, cit. (n. 33), p. 122]. Sobre la teoría del uso normal y las aportaciones de Ihering, cfr. JiméneZ SALCEDo, Ma Carmen, cit. (n. 33), pp. 71-100. No obstante, la opinión anterior no es unánime y hay sectores doctrinales que afirman que Trebacio negaba la acción porque no se daba la condición esencial para el ejercicio de la misma, a saber, no se trataba de agua de lluvia [Gómez Royo, Enrique, cit. (n. 21), pp. 89-90]. Según Manlio Sargenti también es difícil que se diese el requisito de que el agua de lluvia se mezclase con la de la fuente al impedirlo la propia construcción del edificio de la lavandería [SARGENTI, Manlio, cit. (n. 17), p. 34]. Para Bonfante no habría verdadera inmisión porque el agua discurre de forma natural, "sin aumentar ni en cantidad ni en 
fuese dirigida o canalizada a un punto en concreto (conrivat) o que el agua que entrase en el fundo vecino fuese agua sucia o contaminada $(\text { spurca })^{36}$. Precisamente, es en este último punto donde encontramos la protección medioambiental. Aunque, como hemos podido comprobar, son pocos los que han analizado el pasaje en este sentido, resulta evidente la preocupación por evitar la contaminación del agua por posibles vertidos de sustancias usadas para el lavado y ello con independencia de que nos situemos en el marco más amplio de las relaciones de vecindad ${ }^{37}$.

Es evidente la implicación ambiental de un fragmento de Ulpiano donde éste recoge el pensamiento de Labeón sobre la contaminación de las conducciones de agua (básicamente acueductos), lo que resulta lógico dada la importancia de estas construcciones para los romanos ${ }^{38}$. Así, se prohibía

fuerza" [Bonfante, Pietro, Las relaciones, cit. (n. 33), p. 36].

${ }^{36} \mathrm{En}$ ambos casos se debería indemnizar al vecino perjudicado. El problema es que no se indica cómo impedir estos hechos. Zamora Manzano, con una visión amplia, sostiene que sería posible tanto la actio aquae pluviae arcendae (cuando se tratase de agua de lluvia o de aqua pluvia mixta cum ali, es decir, en los supuestos en los que se admite) como cualquier otra acción que permitiese "tutelar el patrimonio hídrico en defensa de la contaminación, como es el interdicto quod vi aut clam o la actio negatoria" o incluso la actio de iniuriarum en conexión con D. 47,11,1,1 [Zamora Manzano, José Luis, cit. (n. 21), pp. 25-26]. Cfr. Gómez Royo, Enrique, cit. (n. 21), p. 91. Bonfante se muestra partidario de la acción negatoria [Bonfante, Pietro, Las relaciones, cit. (n. 33), p. 37]. Para Jiménez Salcedo sería contradictorio que "contra la opinión de Trebacio, Ulpiano parezca conceder la actio aquae pluviae arcendae para el supuesto en el que el agua inmitida haya sido canalizada o esté sucia" [Jiménez SALCEDo, Ma Carmen, cit. (n. 33), p. 98]. Sargenti, tras analizar con detenimiento las posibles interpolaciones, la intervención de los compiladores y las incorrecciones vendría a concluir que la jurisprudencia clásica concedía la acción negatoria, pero los compiladores "utilizzando liberamente il pensiero originario, si contentano di dire che l'immissio potest impediri, senza determinare con quale mezzo", por lo que "l'imprecisione di linguaggio diviene strumento per allargare il campo di applicazione dell'a.a.p.a" que en el Derecho justinianeo se rige por criterios más flexibles y, en consecuencia, el término genérico impediri se referiría a la actio aquae pluviae arcendae [SARgenti, Manlio, cit. (n. 17), pp. 37-38]. Para Sitzia la cuestión no está resuelta y existirían argumentos tanto a favor de la acción negatoria como de la actio aquae pluviae arcendae [SitZIA, Francesco, cit. (n. 33), pp. 159-160].

${ }^{37}$ Sobre la actividad de las lavanderías o tintorerías y su repercusión en el medio ambiente y, en concreto, su peligrosidad para la salubridad de las aguas por los productos utilizados, así como su importancia para la economía, consultar Di PoRTo, Andrea, cit. (n. 33), pp. 68-73.

${ }^{38}$ En cuanto a las normas para proteger los acueductos, las sanciones previstas para los que dañasen las conducciones de aguas y las funciones de los curatores aquarum, véase: Zamora Manzano, José Luis, cit. (n. 21), pp. 31-33. Paolo Fedeli sostiene que serían los curatores aquarum los encargados de velar por mantener la pureza del agua, castigando con severidad a los infractores [FEDELI, Paolo, cit. (n. 14), p. 60]. Respecto a la construcción de acueductos en Roma, siguiendo la obra de Vitruvio, De 
hacer cualquier cosa en un fundo (cavar, podar, edificar, plantar, talar [...]) que pudiese afectar (ensuciar, corromper, deteriorar, alterar, estropear [...]) al agua que se conduce ${ }^{39}$, es decir, una serie de actuaciones (que se enumeran expresamente) que perjudicasen el agua canalizada ${ }^{40}$.

También se contemplaba en el ordenamiento jurídico romano la obligación de limpiar los acueductos por parte de los poseedores de los terrenos por los que pasaban los mismos, librándose éstos de cualquier otra carga que les impidiese realizar esta tarea. El incumplimiento se sancionaba con la pérdida de bienes ya que el fisco se quedaba con el predio de aquél cuya

architectura, se puede acudir a García Quintas, María de las Mercedes, cit. (n. 21), pp. 52-60.

${ }^{39}$ D. 43,20,1,27 (Ulp., 70 ad ed.). Andrea di Porto especifica que Labeón se refiere al interdicto de aqua cotidiana y al interdicto de aqua aestiva recogido en D. 43,20 y manifiesta una clara preocupación por proteger el patrimonio hídrico ante cualquier clase de contaminación, a la vez que tiene como objetivo la defensa de la salubridad del agua. La tutela del agua frente a la contaminación, con independencia de si era cotidiana o estival, es decir, de cualquier especie, se haría, de forma complementaria, mediante el interdicto quod vi aut clam [Di PorTo, Andrea, cit. (n. 33), pp. 53-56]. Sobre este título interdictal y la legitimación procesal pasiva para el que impedía indirectamente la normal conducción del agua, consultar Betancourt, Fernando, Derecho romano clásico (4a edición revisada y aumentada, Sevilla, Universidad de Sevilla, 2010), pp. 354355. Véase de Betancourt, Fernando, El Libro anónimo "de interdictis". Codex Vaticanus Latinus, $n^{\circ} 5766$ (Sevilla, Universidad de Sevilla, Secretariado de Publicaciones, 1997). Zamora Manzano afirma que en este texto no se imponen sanciones económicas para el que realizaba una actividad que derivase "en una contaminación y alteración del flujo de la conducción sobre un fundo" sino que se establecía la "protección interdictal para evitar (la contaminación) y restablecer la situación en caso de daño” en el agua, resarciendo el mismo. Sin embargo, al contrastar este pasaje con el capítulo 127 de la obra de Frontino, De aquaeductu urbis Romae [véase la edición de KroHn, F. (Leipzig, 1922)], indica que se trataba "de proteger las zonas adyacentes a las obras hidráulicas, en especial los acueductos, prohibiendo edificar, plantar, etc. conminando todo ello con una multa de 10.000 sestercios", constituyéndose una servidumbre legal en los terrenos que se sitúan junto a la conducción [Zamora Manzano, José Luis, cit. (n. 21), pp. 33-34]. Véase: García Quintas, María de las Mercedes, cit. (n. 21), pp. 66-67. En D. 43,20 que se ocupa, como hemos dicho, de las aguas cotidianas se contiene mucha información acerca de los fontes [cfr. Gerez KraEMER, Gabriel M., cit. (n. 13), pp. 75-76 y 230].

${ }^{40}$ Advierte Di Porto que estamos ante una previsión muy amplia que se hace eco de algunas disposiciones de la Lex Quinctia de aqueductibus, que recoge Frontino en De aquaeductu urbis Romae, 129, relativa a los acueductos públicos y que se refiere más a la calidad que a la cantidad del agua [DI Porto, Andrea, cit. (n. 33), p. 55]. La Lex Quinctia de aqueductibus también se refleja en CI. 11,43 [42],1 [del Código hemos seguido la edición de Krueger, Paul, Corpus Iuris Civilis (11 ${ }^{a}$ edición, Berlin, 1954 y reedición anastática, Hildesheim, Weidmann, 1997), II]. Cfr. Gerez Kraemer, Gabriel M., cit. (n. 13), pp. 73 y 80. 
negligencia había contribuido a la ruina del acueducto. Resulta obvio que esta limpieza ayudaba a mantener la salubridad de las aguas que eran conducidas por la instalación y a evitar su contaminación. Por otra parte, se establecía la distancia en pies que se debía respetar a ambos lados del acueducto para plantar árboles (quince pies), debiendo ser cortados si se extendían y sus raíces podían dañar la construcción ${ }^{41}$. Una constitución de Zenón prohibió que se plantasen árboles junto a los acueductos para evitar que sus raíces afectasen a las paredes del mismo y el que lo hiciera sufriría el embargo de sus bienes ${ }^{42}$. En cuanto a las acequias públicas, el espacio donde no se permitían árboles era de diez pies a ambos lados ${ }^{43}$.

Cuestión diferente sería la contaminación del agua de los ríos o del mar por vertidos que dudamos se recogiera en sentido estricto en el Derecho romano ${ }^{44}$, a

${ }^{41}$ Se trata de una Constitución de Constantino del año 330 dirigida a Maximiliano, Consularem aquarum (CI. 11,43 [42],1). El Título 43 [42] del libro XI del Codex está dedicado a los acueductos. Respecto a la limpieza de los acueductos que estaban al descubierto, véase: D. 43,10,1,3 (Pap., de off. aed.).

${ }^{42}$ CI. 11,43 [42],10. Al margen de la contaminación, sobre las desviaciones ilícitas del agua que perjudicaban el abastecimiento, las concesiones y las sanciones por incumplimiento, se puede consultar lo que dice Zamora Manzano, José Luis, cit. (n. 21), pp. 36-38. En cuanto al castigo por la destrucción de los diques que contenían las aguas del Nilo, evitando las inundaciones durante las crecidas, o la tala de los árboles que sujetaban dichos diques que se contempla en D. 47,11,10 (Ulp., 9 de off.proc.) y en CI. 9,38,1, véanse las pp. 38-39. Considera Zamora que "la gravedad de las penas se debe a que es un delito que atenta contra el patrimonio hídrico" y la rotura de los diques ocasionaría un gran impacto ecológico (p. 39).

${ }^{43}$ CI. $11,43[42], 6,1$.

${ }^{44}$ Entendemos un tanto forzada la interpretación realizada por ZAMORA MANZANo, José Luis, cit. (n. 21), pp. 40-43, de D. 43,12,1 pr. (Ulp., 68 ad ed.); D. 43,12,1,15 (Ulp., 68 ad ed.) y D. 43,12,1,17 (Ulp., 68 ad ed.) donde entiende incluida la contaminación ya que, en nuestra opinión, el espíritu de las normas va más bien encaminado a proteger la navegación fluvial y la marítima prohibiendo las actividades (en el río, mar u orillas) que puedan afectar, entorpecer o impedir la misma, así como el estacionamiento de los barcos. Entre dichas actividades se refiere la desviación del agua que ocasione una disminución y la haga más escasa y menos navegable o que se produzca un estrechamiento del cauce, pero nada se dice de posibles vertidos, aunque lógicamente estarían incluidos en la cláusula residual vel si quid aliud fiat si realmente perjudicasen la navegación. Lo mismo pensamos en cuanto a la normativa relacionada con la echazón (D. 14,2,8 [Iul., 2 ex Min.]) que parece dirigida a recuperar la mercancía más que a defender el mar o su litoral de los daños ocasionados por los productos arrojados. Tampoco incide en la contaminación la regulación de la echazón en Partidas, V,9,6. Cuestión distinta es que de forma indirecta se consiga una protección medioambiental, ya que es obvio que todo lo que se arroja al mar contamina y al recuperarlo se minimizan los perjuicios. Hay un interdicto específico para prohibir que en los ríos públicos o en sus orillas se haga o introduzca algo que altere el curso del agua, ocasionando una desviación no autorizada por la correspondiente concesión o una disminución del caudal (D. 
pesar de que la preocupación estuviese presente ${ }^{45}$. Sin embargo, sí que se consideraba la posibilidad de que las legiones acampasen con sus caballos en los márgenes de los ríos y ensuciasen sus aguas, prohibiéndose se manera expresa ${ }^{46}$. Asimismo, los ríos y manantiales (e incluso las fuentes) podían verse contaminados por la sangre de los animales sacrificados en honor a los dioses o de los soldados fallecidos en las contiendas bélicas ${ }^{47}$.

Más interés tendría, desde el punto de vista de la contaminación, un pasaje de Ulpiano que somete al interdicto quod vi aut clam al que hubiera vertido algo en el pozo de un vecino para corromper (contaminar) el agua, al entenderse que lo ha hecho de forma violenta o clandestina, equiparándose a una obra porque el agua viva se considera una parte del campo ${ }^{48}$. Así, "por razones de utilidad y sólo en el contexto del interdicto quod vid aut clam, el jurista habría aproximado el régimen del agua al del terreno en el que se halla" ${ }^{49}$. Subyace la defensa del patrimonio hídrico del fundo frente a cual-

43,13,1 pr. y 1 [Ulp., 68 ad ed.]). Paolo Fedeli conecta el carácter sagrado del agua con el hecho de que cualquier intervención dirigida a regular o modificar su trayectoria solo se permita en caso de extrema necesidad [Fedeli, Paolo, cit. (n. 14), pp. 63-66]. En relación a la protección de las orillas de los ríos públicos mediante el interdicto de ripa munienda, véase: D. 43,15,1 pr. (Ulp., 68 ad ed.). Esta protección se hace extensiva a las orillas de los lagos y estanques en D. 43,15,1,6 (Ulp., 68 ad ed.). Véase: BetancourT, Fernando, Derecho romano, cit. (n. 39), pp. 282-283. Tampoco creemos que tenga relación con la contaminación de las aguas la Constitución de Honorio y Teodosio del año 420 (CI. 12,44 [45],1) relativa a la custodia del litoral y al control de las mercancías transportadas por mar, aunque Zamora Manzano opine que se trata de una inspección "a priori de aquellas mercancías o sustancias que pueden originar un daño mayor en caso de iactus" [Zamora ManZano, José Luis, cit. (n. 21), p. 45]. Aunque contraria a la mayoría de la doctrina, sí que compartimos su interpretación de D. 9,3,6,3 (Paul., 19, ad ed.) sobre la aplicación del edicto de effusis respecto a los vertidos realizados desde una nave y su conexión con la tutela medioambiental en materia de aguas (pp. 45-48).

${ }^{45}$ Bañarse y lavar en aguas públicas eran prácticas cotidianas de los romanos que podían contaminar los ríos [FEDELI, Paolo, cit. (n. 14), p. 60].

${ }^{46}$ Estamos ante una constitución de Graciano, Valentiniano y Teodosio del año 391 contenida en CI. 12,35 [36],12 y CTh. 7,1,13 [edición del Código Teodosiano de Mommsen, Theodor y Krueger, Paul (reedición anastática, Hildesheim, Weidmann, 1990)]. Véase Fedeli, Paolo, cit. (n. 14), p. 61.

${ }^{47}$ Fedeli, Paolo, cit. (n. 14), pp. 67-70. Recoge otros elementos que podían contaminar el agua (entre ellos el plomo de las canalizaciones), en pp. 71-72.

${ }^{48}$ Cfr. D. 43,24,11 pr. (Ulp., 71 ad ed.). Examina con detenimiento el pasaje, planteando los límites y los problemas de la aplicación del interdicto quod vi aut clam en el campo de la contaminación hídrica, Di PORTo, Andrea, cit. (n. 33), pp. 3-14 y 48-53.

${ }^{49}$ Gerez Kraemer, Gabriel M., cit. (n. 13), p. 63. Gerez utiliza este texto en su completo análisis de la titularidad de los fontes (pp. 61-73). Sobre el interdicto quod vi aut clam, cfr. Betancourt, Fernando, Derecho romano, cit. (n. 39), pp. 298-299 o Biondi, Biondo, cit. (n. 34), p. 200. 
quier clase de contaminación ${ }^{50}$.

La referida preocupación del Derecho romano por la pureza de las aguas se refleja en los mecanismos para garantizar la misma. De este modo, se prohibía que se tratase de impedir violentamente la limpieza y reparación de acequias, canales cubiertos o presas por las que discurría el agua ${ }^{51}$, a la que se daba prioridad frente a la reparación de los caminos, dada la importancia del líquido elemento para la vida ${ }^{52}$; haciéndose extensiva dicha prohibición a las fuentes destinadas a contener el agua ${ }^{53}$, pozos, lagos y piscinas ${ }^{54}$. Tanto la limpieza como la restauración de las fuentes y de los sistemas de conducción del agua serían imprescindibles para garantizar la salubridad de la misma ${ }^{55}$.

Se concedía importancia en el ordenamiento jurídico romano a la limpieza y reparación de canales y cloacas ${ }^{56}$, no admitiéndose aquí una denuncia de obra nueva porque se daba prioridad a la salud y a la seguridad pública ${ }^{57}$.

${ }^{50}$ Di Porto, Andrea, cit. (n. 33), p. 3.

${ }^{51}$ D. 43,21,1 pr. (Ulp., 70 ad ed.). Comentan esta disposición y el correspondiente interdicto de rivis, Betancourt, Fernando, Derecho romano, cit. (n. 39), pp. 360361; Zamora Manzano, José Luis, cit. (n. 21), pp. $49-50$ (sobre la contaminación específica de los abrevaderos por acumulación de ganado, véanse las pp. 51-52) y DI Porto, Andrea, cit. (n. 33), pp. 91-92.

${ }^{52}$ D. 43,21,4 (Venul., 1 de interd.). De motivación fundada en la urgencia, habla DI Porto, Andrea, cit. (n. 33), p. 92, nota 289 y p. 96.

${ }^{53}$ D. 43,22,1,6,7 y 8 (Ulp., 70 ad ed.). Se contempla el interdicto de fonte que tendría un fin análogo al interdicto de rivis. Véase Betancourt, Fernando, Derecho romano, cit. (n. 39), pp. 363-366; Di PoRTo, Andrea, cit. (n. 33), pp. 92-93 y 98; GIRARD, Paul Frédéric, Manuel élémentaire de droit romain (4a edición, Paris, Arthur Rousseau éditeur, 1906), pp. 380-381; y Mercier De Lacombe, Auguste St. Hilaire, De la propiété comunale. Des interdits de aqua quotidiana et aestiva, de rivis, de fonte (tesis doctoral, Paris, 1856).

${ }^{54}$ D. 43,22,1,10 (Ulp., 70 ad ed.).

${ }^{55}$ Cfr. Di Porto, Andrea, cit. (n. 33), p. 95.

${ }^{56}$ Un problema generalizado en el mundo antiguo fue la eliminación de los residuos orgánicos. El sistema de saneamiento era rudimentario y, a veces, inexistente en las grandes ciudades. Mientras los griegos estaban más preocupados por la belleza de sus núcleos urbanos; los romanos, más prácticos y eficientes, se habían encargado de construir carreteras, acueductos y cloacas [FEDELI, Paolo, cit. (n. 14), p. 67]. En cuanto al significado del término cloaca, indica San Isidoro, "Cloacae dictae quod his percolantur aquae". Señala que las primeras cloacas que hubo en Roma las construyó Tarquino Prisco para que cuando hubiese una inundación, a consecuencia de las lluvias, el agua saliese a través de ellas, evitando que las riadas erosionasen los cimientos de la ciudad [SAN Isidoro, Etymologiarum, XV, 2,25, edición bilingüe de Oroz, J. y Marcos, M. A., cit. (n. 22), II, pp. 230-231].

${ }^{57}$ D. 39,1,5,11 (Ulp., 52 ad ed.). La idea que subyace en este pasaje es la utilidad publica, es decir, se protegen unos intereses superiores a los particulares y por este motivo se permiten las obras y no cabe denuncia [Di PoRTo, Andrea, cit. (n. 33), p. 93, nota 
En esta línea, había un interdicto que trataba de garantizar la reparación y limpieza de las cloacas particulares prohibiendo que se usara violencia para impedir estas tareas ${ }^{58}$. Se trataba del interdicto de cloacis $^{59}$. El fin era evitar pestilencias que pusieran en riesgo la salubridad y la seguridad de las ciudades, es decir, se basaba en razones de utilidad pública, ya que las inmundicias de las cloacas provocaban malos olores y ruinas ${ }^{60}$. Incluso se admitía la entrada en fundo ajeno rompiendo el pavimento, si era necesario

289 y pp. 96-97, 122-123 y 130-131].

${ }^{58}$ D. 43,23,1 pr. (Ulp., 71 ad ed.). En cuanto a las cloacas públicas, se trataba de evitar que se hicieran o introdujeran en ellas cosas indebidas que pudieran dañarlas o deteriorarlas, debiendo, en tal caso, ser restituidas en su estado originario por el particular que las hubiese estropeado en virtud del interdicto de cloacis, es decir, "se prohíbe de forma radical cualquier facere o immittere en la misma” [D. 43,23,1,15 y 16 (Ulp., 71 ad ed.)] [GARCía SÁnChez, Justo, cit. (n. 33), pp. 24-25 y 89]. Comenta la discutida naturaleza prohibitoria o restitutoria de los interdictos para la limpieza y mantenimiento de las cloacas privadas y públicas, Di PorTo, Andrea, cit. (n. 33), pp. 118-131; Zamora Manzano, José Luis, cit. (n. 21), pp. 58-67 o Betancourt, Fernando, Derecho romano, cit. (n. 39), pp. 368-371. Sobre la facultad de cualquier persona de que su cloaca privada desaguase en la pública sin que los vecinos pudieran impedirlo, en relación con D. 43,23,1,9 (Ulp., 71 ad ed.), véase: García SÁncheZ, Justo, cit. (n. $33)$, pp. 24 y 131. Indica que en la ciudad se reconocía el derecho de cualquier propietario de colocar, "bajo las casas vecinas, los tubos de conducción de las aguas residuales hasta darles salida en la vía pública”. Se trataba de un derecho ubicado en las relaciones de vecindad que limitaba el derecho de propiedad, aunque entre los motivos de esta restricción figuraba la salud pública. Sin embargo, no se podría ejercer este derecho si se causaba daño en la vía pública, es decir, si al introducir la cloaca en la vía, ésta se hacía menos practicable [D. 43,8,2,26 (Ulp., 68 ad ed.)] o si la pestilencia fuera insoportable [D. 43,8,2,29 (Ulp., 68 ad ed.)]. Estaríamos, en palabras de García Sánchez, ante un límite impuesto por la coexistencia social [GARCía SÁNCHEZ, Justo, cit. (n. 33), p. 142]. Para Jiménez Salcedo, se protegía el interés general de la comunidad por encima de los intereses de un propietario en particular y resulta evidente el criterio de la necesidad social ya que "el uso y goce de los lugares públicos es general y socialmente necesario", de forma que se limitaba el derecho de los propietarios cuando su ejercicio se realizase "en detrimento de la satisfacción de las necesidades comúnmente reconocidas de usar y disfrutar los lugares y las vías públicas” [JiménEZ SALCEDo, Ma Carmen, cit. (n. 33), p. 126; expone la teoría de la necesidad social de Bonfante en pp. 103-126]. Cfr. PONTE, V., cit. (n. 30), pp. 188 y 194-195 y Di PorTo, Andrea, cit. (n. 33), pp. 132-141.

${ }^{59}$ Las deficiencias en el sistema de alcantarillado serían una de las principales fuentes de contaminación y este interdicto trataba de subsanarlas. Además, las aguas residuales podían contaminar el aire y hacerlo irrespirable [FEDELI, Paolo, cit. (n. 14), p. 67].

${ }^{60}$ D. 43,23,1,2 (Ulp., 71 ad ed.) y D. 43,23,1,7 (Ulp., 71 ad ed.). El interdicto se haría extensivo no solo a la reparación y limpieza de las cloacas ya existentes, sino también a la construcción de una nueva, siempre que no se hiciese en sitio público, ya que la utilidad sería la misma [D. 43,23,2 (Venul., 1 de interd.)]. Véase: Di Porto, Andrea, cit. (n. 33), pp. 134-138. 
para limpiar la cloaca (y suponemos que para repararla), siempre que se restaurasen los posibles daños ${ }^{61}$ y se prestase caución en tal sentido ${ }^{62}$, sin que cupiese denuncia ${ }^{63}$. En el concepto de cloaca se incluiría la tubería y la cañería ${ }^{64}$. El saneamiento y la conservación de las cloacas y de los sistemas de desagües jugarían un papel fundamental para prevenir la contaminación de las aguas limpias manteniendo éstas separadas de las fecales ${ }^{65}$, aparte de evitar olores fétidos ${ }^{66}$. Así, para garantizar la salubridad era fundamental, de un lado, incentivar la construcción de cloacas y de otro, hacer lo posible para las cloacas no contaminasen ${ }^{67}$.

${ }^{61}$ D. 43,23,1,12 (Ulp., 71 ad ed.). Cfr. DI PoRTo, Andrea, cit. (n. 33), pp. 127-128 y 131.

${ }^{62}$ D. 43,23,1,14 (Ulp., 71 ad ed.).

${ }^{63}$ D. 43,23,1,13 (Ulp., 71 ad ed.).

${ }^{64}$ D. 43,23,1,6 (Ulp., 71 ad ed.).

${ }^{65}$ Sobre la cloaca como uno de los principales factores contaminantes y la relación entre cloaca y salubridad, véase Di PorTo, Andrea, cit. (n. 33), pp. 114-115. Di Porto analiza con detalle el problema de la evacuación de residuos para el que la cloaca supone una "solución", en pp. 115-118.

${ }^{66}$ Respecto a los malos olores, véase: D. 43,8,2,29 (Ulp., 68 ad ed.) donde se permite el ejercicio del interdicto ne quid in loco publico contra el que en un lugar público hiciera algo que provocara olores pestilentes. Para Justo García Sánchez "se protege el interés de la colectividad por encima de cualquier interés privado", en concreto, "el goce general al que tienen derecho, en un bien público, todos los ciudadanos" "frente a una actividad en principio lícita, que provoca una disminución en el disfrute por los demás" [García Sánchez, Justo, cit. (n. 33), pp. 140-141]. Cfr. Ponte, V., cit. (n. 30), pp. 188 y 194-195. En cuanto a los humos, consultar D. 47,10,44 (Iavol., 10 ex post. Lab.) y D. 8,5,8,5 (Ulp., 17 ad ed.). En este último texto se alude al problema de los humos procedentes de una fábrica de quesos, permitiéndose que se echaran sobre edificios superiores si había una servidumbre en tal sentido y prohibiéndose en caso contrario. Evidentemente, el problema no es el daño ocasionado al medio sino la injerencia en el derecho de propiedad [Jordano FraGa, Jesús, cit. (n. 2), p. 18]. Examina con detenimiento este pasaje García Sánchez concluyendo que "salvo que exista una servidumbre constituida no son lícitas ni las inmisiones de sólidos (en concreto se habla de piedras), ni las de líquidos (se habla de agua) ni las de gases (se analiza el caso del humo)" [GARCía SÁNCHEZ, Justo, cit. (n. 33), pp. 48-59 y 96, cita en p. 58]. Este fragmento del Digesto es el punto de partida de Carmen Jiménez Salcedo para plantear el concepto de immissio y afirma que es el núcleo central del régimen jurídico de las relaciones de vecindad porque contiene las claves para solucionar el problema de las inmisiones estando prohibidas "salvo que se haya constituido una servidumbre cuyo contenido sea precisamente la realización de una inmisión” [JIMÉnEz SALCEDo, Ma Carmen, cit. (n. 33), pp. 36-38 y 54-59]. Sobre el problema de los humos en general de D. 47, 10, 44, véase Jiménez SALCEdo, Ma Carmen, cit. (n. 33), pp. 170-171 y GARCÍA SÁNCHEZ, Justo, cit. (n. 33), pp. 183-184. Fedeli expone la controversia doctrinal en torno a D. 8,5,8,5 (Ulp., 17 ad ed.) [FEDELI, Paolo, cit. (n. 14), p. 72].

${ }^{67}$ Di Porto, Andrea, cit. (n. 33), p. 118. 


\section{DERECHO HISPANO-MUSULMÁN}

No es desconocido el interés de los musulmanes por el agua y la trascendencia que otorgaban a este elemento a diferentes niveles. En consecuencia, y por motivos diversos, no desatendieron el tema de la contaminación o, al menos, de la limpieza de las aguas ${ }^{68}$. Ya en el Corán se puede comprobar la importancia que se le otorgaba, regulándose su distribución y utilización desde un punto de vista espiritual y jurídico ${ }^{69}$. Al contenerse estas normas en el texto coránico obligan al creyente en el "plano jurídico-religioso" y su incumplimiento lleva aparejada las correspondientes sanciones ${ }^{70}$.

En la España islámica había preocupación por el mantenimiento, limpieza, utilización y distribución equitativa del agua, regulándose el uso de las acequias y estableciéndose turnos para el riego ${ }^{71}$. Todo esto se refleja en las distintas fuentes jurídicas ${ }^{72}$. Muchas normas y costumbres islámicas se

${ }^{68}$ Véase, al respecto, el completo trabajo de MARTínez Almira, Ma Magdalena, Derecho de Aguas. Malos usos y contaminación en el Derecho andalusi, en AHDE., 76 (2006), pp. 323-407.

${ }^{69}$ En cuanto a la necesidad de conservar el agua, Corán, 15,22 y 25, 48-50. Hemos seguido la edición del Corán preparada por Cortés, Julio (Barcelona, 1986; $5^{\text {a }}$ edición revisada, Editorial Herder, 1995), ad casum, pp. 318 y 425. Para comprender la trascendencia del Corán para el Derecho islámico y su ubicación en la estructura jurídica, se puede consultar Mandirola Brieux, Pablo, Introducción al Derecho islámico (Madrid-Barcelona, Marcial Pons, 1998), pp. 57-62; Martos Quesada, Juan, Introducción al mundo jurídico de la España musulmana (Madrid, Ediciones G. Martín, 1999), pp. 17-21; o Coulson, Noel J., Historia del Derecho islámico (traducción de María Eugenia Eyras, Barcelona, edicions Bellaterra, 1998), pp. 19-29.

${ }^{70}$ Cfr. Martínez Almira, Ma Magdalena, cit. (n. 68), p. 328.

${ }^{71}$ En cuanto a los contratos de riego, derechos, obligaciones, riesgos, plazos, servidumbres, condiciones de validez, efectos jurídicos y reclamaciones, véase: MARTínEZ Almira, $M^{a}$ Magdalena, cit. (n. 68), pp. 342-345 y 350-352; y, con carácter más general, López Ortiz, José, Derecho musulmán (Barcelona-Buenos Aires, Labor, 1932), p. 203.

${ }^{72}$ Martínez Almira se remonta al Corán y a la Sunna para analizar los preceptos que conceden al agua "un valor fundamental para la consecución por el creyente musulmán de fines tanto espirituales como materiales", afirmando, tal vez en exceso, que en el texto coránico se contiene "un sucinto derecho de aguas". Por su parte, la Sunna pondría de manifiesto la importancia del agua para las abluciones. También recurre a otras fuentes (incluyendo tratados, que contienen normas de comportamiento atinentes al ámbito espiritual, y formularios notariales) que aportan más datos sobre la trascendencia del agua, su uso y la conveniencia de un reparto equitativo, atendiendo a los principios de solidaridad y equidad, entre la población islámica y no islámica [MARTínez Almira, $\mathrm{M}^{a}$ Magdalena, cit. (n. 68), pp. 325-328]. En cuanto a la importancia de los formularios notariales para la Historia del Derecho hispanomusulmán, véase: MARTOs QUESADA, Juan, cit. (n. 69), p. 83. En particular, por su incidencia en el tema que nos ocupa, po- 
aplicarían en la España cristiana, llegando a formar parte de nuestro Derecho histórico. Así, existían autoridades con funciones de policía para controlar todas las cuestiones relacionadas con el agua que se mantendrán tras la conquista cristiana con algunas modificaciones y variantes ${ }^{73}$. En concreto, había un juez o cadí de las aguas que tenía entre sus competencias arbitrar en los conflictos ocasionados por el derecho de riego ${ }^{74}$.

Desde el punto de vista jurídico, la regulación de las aguas en el Derecho andalusí se efectuaba con un criterio utilitarista, en un doble sentido, de un lado, como un "recurso de la naturaleza para la purificación del creyente", es decir, un factor imprescindible para alcanzar la limpieza corporal previa a la oración; y de otro, como elemento de primera necesidad "para el sustento y buen funcionamiento del organismo" y recurso susceptible de aprovecha-

demos mencionar el Formulario notarial hispano-árabe, por el alfaqui y notario cordobés Ibn Al-'Attār (edición de Chalmeta, Pedro y Corriente, F., Madrid, Academia Matritense del Notariado-Instituto Hispano-Árabe de Cultura, 1983).

${ }^{73}$ Refiere estos oficiales y sus funciones, De Diego Velasco, María Teresa, Las Ordenanzas de las Aguas de Granada, en En la España Medieval, 4 (1984), pp. 253-256. Un ejemplo de la supervivencia de prácticas y usos musulmanes en la España cristiana lo encontramos en las normas y reglamentaciones de los regadíos y sistemas de cultivo de la huerta murciana. Alfonso X dejará en manos del Concejo la "partición del agua" determinando, en un texto de 1267, que "las aguas de las acequias serán partidas entre cristianos y moros conforme a derecho". En el siglo XIV, los acuerdos y disposiciones del Concejo se recogerán en una colección de Ordenanzas de la Huerta de Murcia, llamada "Libro del Agua", donde se establecen garantías jurídicas para el regadío, se regula el reparto del agua, la forma de toma, las horas de riego, etc. [CERDÁ RuizFunes, Joaquín, Características histórico-jurídicas de los riegos, en El Libro de la Huerta de Murcia (Ayuntamiento de Murcia, 1973) y en Estudios sobre instituciones jurídicas medievales de Murcia y su Reino (Academia de Alfonso X el Sabio, Murcia, 1987), pp. 487-504, ad casum, pp. 494-497).

${ }^{74}$ Cfr. Martos Quesada, Juan, cit. (n. 69), p. 67. Sobre las competencias de estos jueces, véase: MARTínez Almira, Ma Magdalena, cit. (n. 68), pp. 350-351 y 393-394. Hay que destacar la figura del sobreacequiero. Se trataba de un oficial "experto y encargado de velar por la justa distribución y reparto de las aguas" que "podía prestar consejo en cuantas cuestiones litigiosas se presentaran ante el juez” (pp. 388-399). Respecto al cargo de sobreacequiero y su falta de uniformidad, se puede consultar: DE DiEgo Velasco, María Teresa, cit. (n. 73), p. 254. En general, le correspondía la limpieza de los canales y de las acequias y podía imponer multas a los que no cumpliesen las normas. En Murcia, era potestad del Concejo la designación anual de los diferentes oficiales como cequieros, sobreacequieros y hombres buenos encargados de ordenar e inspeccionar la limpieza anual de acequias, azarbes y azarbetas. En el Libro del Agua se determinaba que el "sobrecequiero castigará al hombre que por su autoridad tomare agua que no fuese suya y pagará una caloña” [CERDÁ Ruiz-FunEs, Joaquín, cit. (n. 73), pp. 486-797]. 
miento común (agua para beber y agua para regar) ${ }^{75}$. El agua que se utilizaba para que el creyente se purificase obligatoriamente antes de orar (aunque no era el único medio $)^{76}$ tenía que estar perfectamente limpia y no contener ninguna impureza 77 . Por ello, se debían evitar "las construcciones o conducciones de agua por las que discurrieran aguas fecales o impuras próximas a la mezquita", debiendo corregirse la inclinación si ya estuviesen hechas o prohibiéndose las mismas. Incluso se podía ordenar su demolición con todos los gastos a costa del responsable, con especial atención a las letrinas, $y$ siempre que el perjuicio quedase demostrado. A la hora de urbanizar, había que tener en cuenta que las infraestructuras básicas estuvieran enterradas y bien canalizadas para que no afectasen a la salud pública, ni interfiriesen en los suministros de agua limpia a las mezquitas ${ }^{78}$. Especial atención se dedicaba, por tanto, a la contaminación del agua y se utilizaba una terminología específica tanto para la acción de ensuciar como respecto a los vertidos que perjudicaban el agua y la hacían impura ${ }^{79}$. En cualquier caso, estamos ante una preocupación de limpieza con fines espirituales, más que relativa a la protección del medio ambiente ${ }^{80}$.

Diferente es la regulación del uso y aprovechamiento del agua destinada al consumo humano o al riego. Así, para garantizar la salubridad del líquido elemento, se disponía que las aguas limpias y las sucias estuviesen perfectamente separadas, de modo que los canales de desagüe y las aguas sucias estarían bajo tierra. Las letrinas tampoco podían construirse en las

${ }^{75}$ Esto responde, sin duda, a la presencia constante del elemento religioso en el Derecho musulmán y a la propia fundamentación religiosa de todo lo jurídico [MARTOS Quesada, Juan, cit. (n. 69), pp. 15-17 o Aguilera Pleguezuelo, José, Estudios de las normas e instituciones del Derecho islámico en Al-Andalus (Sevilla, Guadalquivir ediciones, 2000), p. 15]. Cfr. Martínez Almira, Ma Magdalena, cit. (n. 68), pp. 328-329 y 335-345. En cuanto a las fuentes (ríos, pozos, fuentes propiamente dichas, estanques, balsas, mecanismos hidráulicos, etcétera) de las que procede el agua, consultar pp. 328-330. La descripción del mapa hidrológico de la España musulmana como factor condicionante del reparto del agua y de la adopción de medidas legales respecto a la administración y gestión de las aguas, así como los efectos jurídicos de su uso o mal uso, se contienen en pp. 330-335.

${ }^{76} \mathrm{La}$ prohibición de orar impuro se recoge en Corán, 4, 43 y 5, 6 [edición de CoRTÉs, Julio, cit. (n. 69), pp. 154-155 y 175-176, respectivamente]. Sobre las causas que hacen perder la pureza y obligan a la ablución y las características de este ritual, véase Martínez Almira, Ma Magdalena, cit. (n. 68), pp. 337-339 y nota 76.

${ }^{77}$ Cfr. López Ortiz, José, cit. (n. 71), pp. 110-111.

${ }^{78}$ Martínez Almira, Ma Magdalena, cit. (n. 68), pp. 340-341 y 347.

${ }^{79}$ Así lo indica Martínez Almira, Ma Magdalena, cit. (n. 68), p. 323, nota 1 y p. 383 , nota 266.

${ }^{80}$ Corán, 5, 6 [edición de CoRTÉs, Julio, cit. (n. 69), pp. 175-176]. Aquí se especifica cómo había que hacer la ablución previa a la oración. 
orillas de los ríos ${ }^{81}$.

En principio, según la tradición islámica, el agua no podía ser objeto de propiedad privada ${ }^{82}$ aunque la jurisprudencia iría abriendo, poco a poco, la posibilidad de ocupación, de forma que se entendía que pertenecían al propietario de un fundo, las aguas que había recogido en aljibes o cisternas y las que manaban de pozos o fuentes abiertos en terrenos de propiedad $\operatorname{privada}^{83}$.

Con carácter general, la tutela de los recursos hídricos tenía por objeto el agua de la lluvia, la de los ríos (sobre todo frente a las obras que pudieran afectar a su caudal o a los derechos de los demás), los pozos y las fuentes o manantiales ${ }^{84}$.

El agua de la lluvia ${ }^{85}$ (destinada básicamente al consumo humano) se consideraba "un beneficio del cielo" y un bien de la comunidad, susceptible de aprovechamiento por cualquiera, según las normas. Su protección competía a todos, de modo que se castigaba especialmente lavar en estas aguas, porque se ensuciaba o "canalizar aguas fecales por los mismos espacios por donde

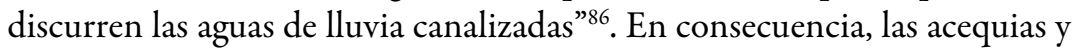
canalizaciones de agua debían también mantenerse limpias.

Los pozos eran "bienes de utilidad pública" y los usuarios tenían que velar por su cuidado y mantenimiento, sobre todo de aquéllos que estaban situados en las mezquitas que no podían verse afectados "por inmundicias

${ }^{81}$ Martínez Almira, Ma Magdalena, cit. (n. 68), pp. 341-342 y 350. Para garantizar la higiene del agua existía una detallada reglamentación sobre la construcción de letrinas y canalización de inmundicias, ya que la limpieza del agua era competencia de las autoridades públicas y de la comunidad en su conjunto (p. 368).

${ }^{82}$ Mandirola Brieux, Pablo, cit. (n. 69), p. 89.

${ }^{83}$ López OrTiz, José, cit. (n. 71), pp. 176-177.

${ }^{84}$ Cfr. Martínez Almira, Ma Magdalena, cit. (n. 68), pp. 346-360. Otros recursos como estanques, embalses o el agua contenida en aljibes, cisternas o depósitos también tuvieron cierto interés, pero al tratarse de aguas estancadas y no renovadas se entendía que eran impuras y no servían para fines espirituales y otras necesidades, es decir, no tendrían la misma importancia para los miembros de la comunidad islámica, salvo excepciones y siempre que cumplieran una serie de requisitos (pp. 356 y 358359). Las aguas estancadas no potables se podían destinar a limpieza de letrinas, riego o abrevadero de animales (pp. 359-360).

${ }^{85}$ Son numerosas las ocasiones en las que el Corán hace referencia al agua de lluvia y a su trascendencia: Corán, 2, 22; 2, 164; 6, 99; 7, 57; 10, 24; 13, 1; 14, 32; 15, 22; 16, $10 ; 18,45 ; 20,53 ; 22,63 ; 23,18 ; 25,48 ; 27,60 ; 30,48-50$ ó 31,10 .

${ }^{86}$ Martínez Almira, Ma Magdalena, cit. (n. 68), pp. 346-347. En cuanto a las obras para un adecuado reparto y canalización del agua de lluvia, los perjuicios que éstas podían causar a fundos vecinos y los requisitos para interponer demanda, véanse las pp. 347-348. Recordemos que este tipo de cuestiones también estaban previstas por el Derecho romano. 
ni sustancias que tornaran el agua inaprovechable" 87 . En todo caso, se debía evitar la contaminación de un pozo destinado al consumo humano o de animales, así como inundarlo con aguas fecales ${ }^{88}$.

En cuanto a las fuentes, su agua era "susceptible de uso y de apropiación", siguiendo criterios de utilidad y también tenía que mantenerse libre de impurezas o suciedad especialmente cuando se destinaba a fines espirituales o religiosos ${ }^{89}$.

$\mathrm{Al}$ margen de una serie de circunstancias (provocadas por la naturaleza o por el hombre) que podían limitar, impedir el uso del agua y, a su vez, perjudicar gravemente el medio ambiente (lluvias torrenciales e inundaciones, sequía, plagas, heladas $[. .].)^{90}$, se entendía que el agua, sin atender a su procedencia (lluvia, pozos, fuentes o mar), se volvía impura cuando en ella caía un animal muerto con independencia de su tamaño o si se "vertiera sangre, o la hubiera tocado un infiel o una persona consumidora de vino, o hubieran recibido las defecaciones o aguas menores de perro o gato" o hubiese sido utilizada por otra persona para sus abluciones o si la había tocado infiel, perro, gato ave carnicera o animales carroñeros ${ }^{91}$.

${ }^{87}$ Como hemos indicado, se debían evitar "las construcciones y canalizaciones que pusieran en peligro la pureza del agua" para fines espirituales, que serían prohibidas y demolidas y los infractores sancionados. Cfr. Martínez Almira, Ma Magdalena, cit. (n. 68), p. 353. También se protegían los pozos para fines agrícolas sobre todo frente a la mengua de agua y se adoptaron medidas para garantizar su buen uso (distancias, perjuicios, acciones y plazos para ejercerlas o medidas cautelares [...]) (pp. 353-356).

${ }^{88}$ Pablo Mandirola Brieux habla del "harim de un pozo". El término "harim" deriva de la palabra "harama" (ser sagrado) y se refiere a bienes comunales, de modo que el "harim" del pozo "lo constituye el espacio de terreno que lo circunda, en el cual no puede establecerse nada que impida su acceso o que perjudique el agua”, es decir, no se podría hacer ninguna edificación, ni otro pozo que lo desecase ni nada que pudiera llegar a contaminar el agua. Y esto mismo sería aplicable a los manantiales o a cualquier otra conducción del agua. En cuanto a los límites del "harim", precisa que el propio Mahoma lo estableció en un radio de cuarenta codos y en el caso de un manantial en quinientos codos [Mandirola Brieux, Pablo, cit. (n. 69), pp. 89-90].

${ }^{89}$ Cfr. Martínez Almira, Ma Magdalena, cit. (n. 68), p. 356.

${ }^{90}$ Especial atención presta, Martínez Almira, entre estas circunstancias, a la merma de la cuota de agua o disminución de su caudal por causas naturales o por la acción del hombre (por ejemplo, la desviación o modificación del curso inicial) y a sus consecuencias y reparación de los daños que esto ocasionaba [Martínez Almira, Ma Magdalena, cit. (n. 68), pp. 361-366 y pp. 370-376].

${ }^{91}$ Tampoco se podía hervir el agua ni calentarla al sol, ni colocarla en recipiente sucio [Martínez Almira, Ma Magdalena, cit. (n. 68), pp. 366-367]. Asimismo, se debía evitar que una construcción (casa, cementerio, horno, molino [...]) afectase al agua corriente. Cualquiera que realizaba una obra sin autorización y causaba daños a las aguas o modificaba su curso tenía que reparar los perjuicios y hacer que la situación volviese a su estado anterior, corriendo con todos los costes (pp. 369-370). Esto mismo se contemplaba en Derecho romano y en nuestro Derecho histórico. 
Básicamente preocupaba al Derecho islámico la contaminación de las aguas en zonas públicas (sobre todo las próximas a la mezquita) y los vertidos de aguas fecales y desperdicios en canales comunales que perjudicaba tanto al uso doméstico como al uso espiritual del agua ${ }^{92}$. Con el fin de proteger la salud pública y en aras de un interés superior, había que presentar denuncia ante el juez cuando se detectaban impurezas en el agua de uso comunitario. En tal caso, se redactaba un acta con los elementos que hubiesen determinado la contaminación ${ }^{93}$. Por otra parte, los desagües viejos o antiguos que podían contaminar el agua debían ser reparados o desviar su contenido ${ }^{94}$.

Desde el punto de vista penal, la consideración de alguna actuación que atentase contra el Derecho de aguas como delito se supeditaba a la discrecionalidad del juez ${ }^{95}$, y lo mismo sucedería con la pena a imponer que, normalmente, dependería del daño causado e implicaría la reparación de éste, en un sistema en el que la composición había sustituido a la venganza ${ }^{96}$.

\section{DeRECho VISIgodo y DERECHO CASTELLANO MEDIEVAL}

Entrando ya en el Derecho histórico español, descubrimos normas dispersas donde se intuye cierta finalidad de protección medioambiental aunque sea de manera indirecta o tangencial al hilo de la tutela de otros intereses. La mayor parte de las disposiciones son relativas a la tala de los árboles, incendios, daños en las viñas, vertidos a la vía pública, destrucción de árboles frutales o daños a los animales (normalmente para defender el derecho de propiedad), siendo más escasas las relacionadas con la salubridad de las aguas, a diferencia de lo que sucedía en el ordenamiento jurídico romano.

En el Derecho visigodo (en particular en el Liber Iudiciorum) y en el Fuero Juzgo encontramos preceptos vinculados con los incendios de los

${ }^{92}$ Cfr. Martínez Almira, Ma Magdalena, cit. (n. 68), pp. 376-377.

${ }^{93}$ En cuanto a este acta y a los efectos jurídicos del mal uso y contaminación del agua, desde el punto de vista del proceso (modelos documentales, inicio, fases, medidas cautelares, testigos y otros medios probatorios y sentencia) caracterizado por la brevedad, véase Martínez Almira, Ma Magdalena, cit. (n. 68), pp. 367-368 y 378-403. Sobre el Derecho procesal en Al-Andalus, consultar Aguilera Pleguezuelo, José, cit. (n. 75), pp. 67-77.

${ }^{94}$ Martínez Almira, Ma Magdalena, cit. (n. 68), p. 369.

${ }^{95}$ Respecto a la discrecionalidad genérica en el Derecho penal islámico, véase: Coulson, Noel J., cit. (n. 69), pp. 140-141.

${ }^{96}$ Así, cuando se realizaban vertidos que contaminaban el agua, la pena consistía en cubrir la zona, ya que las cloacas debían estar cubiertas, junto con el drenado de canales para facilitar el desagüe. El robo del agua se solía castigar con una pena pecuniaria y excepcionalmente corporal, según el valor [Martínez Almira, $M^{a}$ Magdalena, cit. (n. 68), pp. 403-406]. 
montes $^{97}$, la tala de los árboles ${ }^{98}$, la tala e incendios de setos ${ }^{99}$, los daños en las vides ${ }^{100}$ o a los animales ${ }^{101}$, en los que no vamos a entrar pero que parecían también dirigidos a proteger más bien el derecho de propiedad que el medio ambiente o la especie animal ${ }^{102}$. En materia de aguas ${ }^{103}$, se establecía que los grandes ríos (aquéllos en los que entran los salmones u otros peces de mar o que son navegables con fines comerciales) no podían ser cerrados por nadie impidiendo su aprovechamiento por otras personas. Sin embargo, sí que se permitía cercarlos con un seto hasta la mitad donde el agua tuviese más fuerza, quedando libre la otra mitad para el uso de los demás. La inobservancia de lo dispuesto se castigaba con la demolición del seto y con una multa de diez sueldos si se trataba de un hombre de condición noble y de cinco sueldos y cincuenta azotes si era de condición social inferior. Cuando había un señor a cada lado del río, éste no se podía acotar hasta que cada uno demostrase que iba a cercar su mitad, pero uno debía cerrar la mitad de arriba y el otro la de abajo, dejando que el río pasase por el medio. Si nada más se podía cerrar por un lado, se haría de tal modo que se permitiese el paso de las naves y de las redes de pesca. Cuando un señor o un juez demolía el seto que había sido levantado según lo establecido tenía que pagar diez sueldos a su propietario;

${ }^{97}$ Liber Iudiciorum, VIII,2,2 y 3; y Fuero Juzgo, VIII,2,2 y 3 [edición de Los Códigos españoles concordados y anotados (Madrid, Imprenta de la publicidad, 1847), I, pp. 57 y 167]. Sobre los incendios de viviendas en ciudad o fuera de ella, véase Liber Iudiciorum, VIII,2,1 y Fuero Juzgo, VIII,2,1 (pp. 56-58 y 166-168).

${ }^{98}$ Liber Iudiciorum, VIII,3,1 y 8 y Fuero Juzgo, VIII,3,1 y 8 [edición cit. (n. 97), vol. I, pp. 58 y 167]. El título III del libro VIII, tanto en el Liber Iudiciorum como en el Fuero Juzgo, se dedica, con carácter general, a los daños en los árboles, huertos y sembrados.

${ }^{99}$ Liber Iudiciorum, VIII,3,6 y 7 y Fuero Juzgo, VIII,3,6 y 7 [edición cit. (n. 97), vol. I, pp. 57 y 167].

${ }^{100}$ Liber Iudiciorum, VIII,3,5 y Fuero Juzgo, VIII,3,5 [edición cit. (n. 97), vol. I, pp. 57-58 y 167].

${ }^{101}$ Liber Iudiciorum, VIII,4,2,3-8, 10, 13, 15 y 18 y Fuero Juzgo, VIII,4,2-6, 8, 10, 13, 15 y 18 [edición cit. (n. 97), vol. I, pp. 57-58 y 169-170].

${ }^{102}$ Cfr. Jordano Fraga, Jesús, cit. (n. 2), p. 23.

${ }^{103}$ En cuanto al Derecho germánico de aguas, las aguas públicas y privadas, desde el punto de vista de su titularidad y aprovechamiento, y el Derecho de pesca, se puede consultar Planitz, Hans, Principios de Derecho privado germánico (traducción de la $3^{a}$ edición alemana de Carlos Melón Infante, con "prólogo" de Alfonso García Gallo, Barcelona, Bosch, 1957), pp. 113-116. Nada indica de manera directa sobre la contaminación ni sobre el medio ambiente, aunque sí precisa que los propietarios de los ríos privados debían hacer uso de su derecho de aguas de manera "prudente y adecuada”, de forma que "no podían alterar el curso natural ni provocar inundaciones" ni "podían dirigir hacia las aguas materias dañosas" (p. 115). Lógicamente estas actuaciones tendrían su repercusión medioambiental. 
si el que lo destruía era un hombre libre, la sanción sería de cinco sueldos y cincuenta azotes, y si era un siervo, recibiría cien azotes ${ }^{104}$. Aunque en esta disposición se trataba de proteger el derecho de todos a utilizar el río con fines económicos (pesca o transporte de mercancías) podríamos intuir una tutela indirecta de la riqueza piscícola del río y del medio fluvial en general.

Cierta relación con el agua pero menor impacto ambiental, tendría el precepto que establecía que el que derribaba ("quebrantaba") un molino o una presa tenía treinta días para volver a construirlo y reparar lo dañado y además debía pagar una multa de veinte sueldos. Si no lo hacía en el plazo previsto, la multa se duplicaba y se le imponía una pena corporal de cien azotes. Lo mismo se disponía para el que quebrantaba un estanque de agua y si era un siervo debía reparar los daños y recibir cien azotes ${ }^{105}$.

La escasez de lluvia y los periodos de sequía obligarían a regular el hurto del agua ya que de ella dependía el riego y el éxito de las cosechas, al margen de las consecuencias ambientales. Si alguien hurtaba el agua o desviaba el curso del río con "engaño" era multado con un sueldo por cada cuatro horas del día que la hiciera correr por otro lado. Si la cantidad hurtada era pequeña, la multa se reducía a un tercio de un sueldo por cada cuatro horas, debiendo devolverla a quien legítimamente pertenecía. Cuando el autor del delito era un siervo se sustituía la pena pecuniaria por una corporal de cien azotes o de cincuenta según la cantidad ${ }^{106}$. Asimismo, se protegían los molinos, castigándose a los que hurtaban "bierros" u otras piezas con la devolución de lo hurtado, la sanción correspondiente al hurto y cien azotes ${ }^{107}$.

La protección de las aguas, con mayor o menor repercusión ambiental, es una constante en nuestros fueros medievales. La mayoría contiene normas dirigidas a regular su reparto, uso y disfrute, sobre todo para garantizar el riego, para evitar el despilfarro o que alguien utilizase el agua sin derecho (o la robase) perjudicando a terceros, para prohibir las desviaciones del curso natural de las aguas, para reglamentar la construcción, funcionamiento y uso de molinos o para solucionar los problemas que surgían entre molinos situados a diferentes alturas ${ }^{108}$. Más escasas son las disposiciones con pro-

${ }^{104}$ Liber Iudiciorum, VIII,4,29 y Fuero Juzgo, VIII,4,29 [edición cit. (n. 97), vol. I, pp. 61 y 171$]$.

${ }^{105}$ Liber Iudiciorum, VIII,4,30 y Fuero Juzgo, VIII,4,30 [edición cit. (n. 97), vol. I, pp. 62 y 171$]$.

${ }^{106}$ Liber Iudiciorum, VIII,4,31 y Fuero Juzgo, VIII,4,31 [edición cit. (n. 97), vol. I, pp. 62 y 171$]$.

${ }^{107}$ Liber Iudiciorum, VII,2,12 y Fuero Juzgo, VII,2,12 [edición cit. (n. 97), vol. I, pp. 51 y 160$]$.

${ }^{108}$ En cuanto a la importancia de los molinos hidráulicos en la Edad Media, se puede consultar Álvarez Llopis, Ma Elisa, Molinos hidráulicos en Cantabria, siglos $X$ al XIII, en El Fuero de Santander y su época. Actas del Congreso conmemorativo de 
yección medioambiental vinculadas con la prohibición de ensuciar las aguas, con la limpieza, acondicionamiento y mantenimiento de canales, cauces y acequias o con la pesca e indirectamente con la tutela de la fauna. Normalmente, las acequias tenían como finalidad reconducir el agua para el riego y se reglamentaba su utilización para evitar un uso indebido. Las sanciones eran habitualmente pecuniarias y, a veces, corporales. Recogemos una selección de fueros que reflejan lo anterior, refiriendo otros preceptos de los mismos con contenido medioambiental.

El Fuero de Molina de Aragón del año 1154 establecía la obligación de limpiar las acequias cada vez que fuese necesario y, como mínimo, dos veces al año. El que rompía una acequia o una presa o hurtaba el agua era multado con diez maravedís de los cuales, cinco se destinaban a los alcaldes y los otros cinco al saneamiento de las acequias. Para garantizar la salubridad del agua de dichas acequias se prohibía su utilización como abrevadero. Si se llevaban a beber ovejas, la sanción era la entrega de dos carneros y si se trataba de cabras, cerdos o cualquier otro ganado, la multa era de cinco sueldos ${ }^{109}$.

Otros fueros como el de Sahagún ${ }^{110}$, el de Uclés o el de Cuenca penalizaban la tala de árboles ${ }^{111}$ y el segundo, la acción de ensuciar las calles con

su VIII centenario (Santander, Diputación regional de Cantabria, Ayuntamiento de Santander, Universidad de Cantabria, Ediciones de Librería Estvdio, 1989), pp. 411423. Apunta que el "molino hidráulico constituye un fenómeno complejo, en el que participan diversos elementos, técnicos, económicos, jurídicos y sociales” (p. 413). Al mismo tiempo, refiere los problemas que podía ocasionar el agua en el funcionamiento del molino (p. 418).

${ }^{109}$ Fuero de Molina, 30 [Hurtado de Molina Delgado, Julián, Delitos y penas en los fueros de Córdoba y Molina (Córdoba, Servicio de Publicaciones de la Universidad de Córdoba-Ilustre Sociedad Andaluza de Estudios Histórico-Jurídicos, 2003), p. 378]. En este capítulo se regulaba con detalle de dónde se debía tomar el agua para el riego y de qué molino debía proceder según el lugar en el que se encontrasen situadas las fincas (p. 377).

${ }^{110}$ Se trata del fuero otorgado por Alfonso VI a los pobladores de la villa de Sahagún el 25 de noviembre de 1085 .

${ }^{111}$ En el de Sahagún se castigaba la tala de un árbol de raíz con prisión y con la entrega del detenido al abad para que hiciera con él lo que quisiese. La simple sospecha de esta acción permitía la entrada en casa para investigar con el fin de que los árboles, viñas y prados tuviesen la debida protección a favor del monasterio. Cfr. Fuero de Sahagún, 14 y 15 [RodrígueZ, Justiniano, Los fueros del Reino de León (2 vols., León, ediciones leonesas, 1981), II, pp. 38-39; y MuÑoz y Romero, Tomás, Colección de Fueros Municipales y Cartas Pueblas de los reinos de Castilla, León, Corona de Aragón y Navarra (Madrid, 1847; reedición anastática, Madrid, Imprenta de Don José María Alonso, 1972), p. 304]. Véanse: Fuero de Uclés, 55 [edición de Rivera Garretas, Milagros, El Fuero de Uclés (siglos XII-XIV), en AHDE., 52 (1982), p. 284]; y Fuero de Cuenca, V,12 [edición de DE UREÑa y SMENJAUd, Rafael, Fuero de Cuenca (formas primordial y sistemática: texto latino, texto castellano y adaptación del Fuero de Iznatoraf) (Madrid, 
basura o estiércol ${ }^{112}$. También se sancionaban la tala ilícita y los incendios en el Fuero de Zamora de $1208^{113}$.

La prohibición de talar o dañar los árboles se contenía, igualmente, en el Fuero de Salamanca ${ }^{114}$. Especial atención se prestaba a la encina, castigándose quemarla, talarla o quitarle la corteza ${ }^{115}$. Asimismo, se protegían los animales ${ }^{116}$. Los daños a las presas de acequia ajena se multaban con cinco maravedís, la mitad para el denunciante y la otra mitad para el Concejo y si se negaba la acción se debía prestar juramento y el testimonio de dos vecinos ${ }^{117}$. Tampoco se podía echar estiércol ni abono similar en las calles de Salamanca ${ }^{118}$.

En el Fuero de Madrid se recogían precisiones sobre la forma de pescar, encaminadas a la protección de la fauna que habita en el medio acuático. Así, no se podían utilizar determinados utensilios, de forma que si se usaban y se conseguía probar se sancionaba con dos maravedís. También se prohibía, de forma expresa, abrir canales en los ríos y el uso de venenos y, en concreto, echar éstos al río Jarama (entendemos que se podría hacer extensiva la prohibición a cualquier sustancia que pudiera contaminar el agua o perjudicar a la pesca), exigiéndose, en este caso, que se probase con dos testigos y castigándose el incumplimiento con una multa de diez maravedís ${ }^{119}$. Hay otras disposicio-

1935), en http://www.uclm.es/ area/dromano/CR/fuero1.htm].

${ }^{112}$ Fuero de Uclés, 202 [edición de Rivera Garretas, Milagros, cit. (n. 111), p. 285].

${ }^{113}$ Fuero de Zamora, 55 y 56 [CARrasco, Pilar, Estudio Lingüistico del Fuero de Zamora (Málaga-Salamanca-Zamora, Universidad de Málaga, Universidad de Salamanca y Colegio Universitario de Zamora, 1987), p. 49 y RodrígueZ FernándeZ, Justiniano, Los fueros locales de la provincia de Zamora (Salamanca, Junta de Castilla y León, Consejería de Cultura y Bienestar Social, 1990), pp. 259-260].

${ }^{114}$ Se refiere, sobre todo, a castaños y árboles frutales. La multa de cien maravedís era elevada en comparación a otros fueros. Cfr. Fuero de Salamanca, 81 [Fuero de Salamanca, con notas, apéndice y un discurso preliminar de SÁnchez RuAno, J. (Salamanca, Imprenta de Sebastián Cerezo, 1870), p. 28]. En general, la tala de un árbol ajeno se multaba con sesenta sueldos: Fuero de Salamanca, 219 [edición de SÁNCHEZ RuAno, J., cit., p. 65]. En cuanto a la diversidad de opiniones en torno a la fecha de este fuero (siglo VII, año 1081, siglo XIII o incluso principios del XIV), véanse las pp. XIV-XVII.

${ }^{115} \mathrm{El}$ autor de estas acciones era castigado con la pérdida de todos sus bienes y una multa de cinco maravedís: Fuero de Salamanca, 85 [edición de Sánchez Ruano, J., cit. (n. 114), p. 29].

${ }^{116}$ Fuero de Salamanca, 64, 149 y 210 [edición de Sánchez Ruano, J., cit. (n. $114)$, pp. 23, 45 y 62].

${ }^{117}$ Fuero de Salamanca, 159 [edición de Sánchez Ruano, J., cit. (n. 114), p. 48]. Sobre los daños a las presas en general, véase Fuero de Salamanca, 161 [edición de SÁNChez Ruano, J., cit. (n. 114), pp. 48-49].

${ }^{118}$ Fuero de Salamanca, 296 [edición de Sánchez Ruano, J., cit. (n. 114), p. 85].

${ }^{119}$ Fuero de Madrid, rúbrica de pescadores [Cavanilles, Antonio, Memoria sobre el Fuero de Madrid de 1202, en Memorias de la Real Academia de la Historia (Madrid, 
nes en este fuero con implicaciones medioambientales, como la restricción de lavar trapos o "cosas sucias" en la alcantarilla de San Pedro ${ }^{120}$ o de arrojar estiércol a las calles o a cualquier otro lugar no destinado al efecto ${ }^{121}$.

Son varios los títulos del Fuero de Sepúlveda ${ }^{122}$ donde se refleja cierto interés en la tutela de los elementos que integran el medio que rodea al hombre. De entrada, se declaraban de uso común para los habitantes de Sepúlveda los montes, fuentes, ríos, pastos, salinas y minas que se encontraban en sus términos ${ }^{123}$. Se prohibían la tala ilícita ${ }^{124}$, los daños a los animales ${ }^{125}$, los incendios de casas ${ }^{126}$ o de "mieses" ajenas ${ }^{127}$ y el arrojar estiércol o basuras en la villa ${ }^{128}$. No se permitía la pesca en río con veneno y, si esta acción lograba probarse, se castigaba con una multa de cinco maravedís, dos para el alcalde y dos para el demandante ${ }^{129}$. Asimismo, se protegían las especies del

1852), tomo VII, p. 27, en http://www.biblioteca.org.ar/libros/70165.pdf].

${ }^{120}$ Fuero de Madrid, rúbrica de tripas [edición de Cavanilles, Antonio, cit. (n. 119), p. 31].

${ }^{121}$ Cfr. Fuero de Madrid, rúbrica de estercoris [edición de Cavanilles, Antonio, cit. (n. 119), p. 31].

${ }^{122}$ Hemos utilizado la edición del Fuero de Sepúlveda, publicado en el Boletín de Jurisprudencia y Administración y arreglado y anotado por CAllejas, Feliciano (Madrid, Imprenta del Boletín de Jurisprudencia, 1857). El Fuero primitivo de Sepúlveda es del año 1076 y se recoge por Callejas en pp. 7-11 y por Muñoz y Romero, Tomás, cit. (n. 111), pp. 281-286. El texto que seguimos es posterior, de 29 de abril de 1300 y, al parecer, obtuvo sanción real de Fernando IV en el año 1309 y de Juan I en 1379. Se trata de una redacción relacionada con los Fueros de Cuenca y Béjar.

${ }^{123}$ Fuero de Sepúlveda, 2 [edición de Callejas, Feliciano, cit. (n. 122), pp. 17-18].

${ }^{124}$ Fuero de Sepúlveda, 3, 58 y 225 [edición de Callejas, Feliciano, cit. (n. 122), pp. 18, 54 y 99$]$.

${ }^{125}$ Fuero de Sepúlveda, 50, 95, 97, 101, 102 y 188-194 [edición de Callejas, Feliciano, cit. (n. 122), pp. 36, 55, 56, 57 y 80-52]. También se protegían los animales prohibiendo que una bestia sarnosa se mezclase con las demás: Fuero de Sepúlveda, 254 [edición de Callejas, Feliciano, cit. (n. 122), p. 105]. Destaca Callejas el interés de este Fuero por la conservación de los montes, "mieses" y otros plantíos, así como el celo por proteger las bestias y animales, en consideración a que forman parte de la riqueza pública, a los muchos servicios que prestan y a que contribuyen al aumento de los intereses privados y generales del pueblo (p. 105).

${ }^{126}$ Fuero de Sepúlveda, 53 [edición de Callejas, Feliciano, cit. (n. 122), pp. 37-38].

${ }^{127}$ Fuero de Sepúlveda, 128 [edición de Callejas, Feliciano, cit. (n. 122), p. 64].

${ }^{128}$ Esta acción se castigaba siempre que se hiciera de modo que causase algún tipo de daño, o bien a las casas o a la propia calle. La multa era de un maravedí, la mitad para el demandante y la otra para el alcalde. Si se negaba se debía demostrar con un pariente y con un vecino. Cfr. Fuero de Sepúlveda, 251 [edición de Callejas, Feliciano, cit. (n. 122), p. 105].

${ }^{129}$ Fuero de Sepúlveda, 93 [edición de Callejas, Feliciano, cit. (n. 122), p. 55]. 
río, prohibiendo pescar con red barredera o de otro tipo ${ }^{130}$. Al que tomaba agua para regar y no la devolvía a su lugar de origen, ocasionando daños, se le sancionaba con una multa de diez maravedís y el doble del daño ocasionado, siempre que resultase probado, pudiendo presentar dos testigos favorables ${ }^{131}$. Se imponía una pena pecuniaria de dos maravedís, salvo que demostrase su inocencia con dos vecinos como testigos, al que cortase, tomase o causase algún perjuicio en agua ajena ${ }^{132}$.

$\mathrm{Al}$ igual que en el de Sepúlveda, en el Fuero de Béjar (finales del siglo XIII, principios del XIV $)^{133}$ se proclamaba de aprovechamiento común para sus habitantes los montes, fuentes, ríos, pastos, salinas y minas ${ }^{134}$. Además de penalizar la tala ilícita distinguiendo el tipo de árbol ${ }^{135}$, los daños a los animales ${ }^{136}$ y los incendios de sembrados, rastrojos, casas o montes ${ }^{137}$, encontramos varios preceptos dirigidos a proteger las aguas. Del mismo modo que en el Fuero de Sepúlveda, se castigaba al que cogía agua para el riego y luego no la devolvía, causando perjuicios, con una pena pecuniaria de diez maravedís y el doble del daño ocasionado, siempre que no consiguiese demostrar lo contrario con dos testigos favorables ${ }^{138}$. También se imponían multas al que cortaba o tomaba agua ajena ${ }^{139}$. El agua que procedía de

${ }^{130}$ La pena era de cinco maravedís y la pérdida de la red si se probaba con tres vecinos: Fuero de Sepúlveda, 220 [edición de Callejas, Feliciano, cit. (n. 122), p. 91].

${ }^{131}$ Fuero de Sepúlveda, 150 [edición de Callejas, Feliciano, cit. (n. 122), p. 70]. No se permitía pescar en aguas ajenas y si el dueño lo probaba la multa era de cinco maravedís, si pescaba de día y diez, si se hacía de noche: Fuero de Sepúlveda, 219 [edición de Callejas, Feliciano, cit. (n. 122), p. 90].

${ }^{132}$ Fuero de Sepúlveda, 151 [edición de Callejas, Feliciano, cit. (n. 122), p. 70]. Sobre la construcción de molinos y cómo los nuevos no debían perjudicar los ya existentes, véase Fuero de Sepúlveda, 171, 172 y 173 [edición de Callejas, Feliciano, cit. (n. 122), p. 75]. Lo mismo se establecía en el Fuero de Béjar, entre otros, como veremos más adelante, que dedica un mayor número de preceptos a los molinos.

${ }^{133}$ Sobre la fecha del Fuero de Béjar, véase: Gutiérrez Cuadrado, Juan, Fuero de Béjar (Salamanca, Universidad de Salamanca, 1974), pp. 20-27. En cuanto a la relación del Fuero de Béjar con el de Cuenca, a cuya familia pertenece, consultar pp. 27-33. Parte del contenido del Fuero de Béjar coincide con el de Sepúlveda. En torno al parentesco entre ambos, cfr. pp. 33-39.

${ }^{134}$ Fuero de Béjar, 1 [edición de Gutiérrez Cuadrado, Juan, cit. (n. 133), p. 43].

${ }^{135}$ Fuero de Béjar, 2, 117, 118, 136, 138, 141 y 142 [edición de GutiÉrrez CuADRADO, Juan, cit. (n. 133), pp. 43, 59, 60 y 62 ].

${ }^{136}$ Fuero de Béjar, 1011, 1012, 1016, 1020, 1021, 1022, 1023, 1028-1033, 1035 y 1036 [edición de Gutiérrez CuAdrado, Juan, cit. (n. 133), pp. 169, 170, 171 y 172].

${ }^{137}$ Fuero de Béjar, 95, 96, 98, 99, 150 y 151 [edición de Gutiérrez Cuadrado, Juan, cit. (n. 133), pp. 57 y 63].

${ }^{138}$ Fuero de Béjar, 127 [edición de Gutiérrez CuAdrado, Juan, cit. (n. 133), p. 61].

${ }^{139}$ La pena era de dos maravedís sino conseguía demostrar su inocencia con dos vecinos como testigos. Cfr. Fuero de Béjar, 128 [edición de Gutiérrez Cuadrado, 
finca no propia sería conducida por el lugar más adecuado de forma que no perjudicase a nadie ${ }^{140}$. Era competencia de los alcaldes determinar dónde y cómo se debía utilizar el agua para que resultase más provechoso y se provocasen menos perjuicios ${ }^{141}$. La figura del aguador aparece en este fuero como "oficial religioso encargado del agua"142. Para garantizar la salubridad del agua se recogía la obligación de limpiar los bordes de las acequias que correspondía al propietario de las mismas, sancionándose con dos maravedís por cada semana que no lo hiciera ${ }^{143}$. Respecto a los molinos, se planteaba el problema de que los situados abajo perjudicasen a los de arriba por exceso de agua. En el mes de agosto, cuando bajaban las aguas se colocaría una señal y si ésta era cubierta por el molino de abajo, su propietario debía pagar al del molino de arriba diez maravedís y hacer descender el agua; de lo contrario tenía que abonar diez maravedís por cada día que el agua sobrepasase la señal, siempre que se demostrase su culpa ${ }^{144}$. Asunto distinto es que el agua procedente de una presa, canal o molino causase daño en finca ajena; en tal caso, el propietario del molino o presa había de reparar el daño causado y procurar que no volviese a ocurrir, y si no podía impedirlo, estaba obligado a comprar la heredad o a entregar al querellante el doble de su valor a elección de éste ${ }^{145}$. Los molinos, canales y presas nuevos no podían perjudicar a los ya existentes; cuando esto sucedía, tenían que ser demolidos en un plazo de tres días desde que el constructor era vencido en juicio y, si no lo hacía, se le imponía una multa de diez maravedís, la mitad para el demandante y la otra mitad para el alcalde, y el doble del daño por cada día que pasase sin llevar a cabo la demolición ${ }^{146}$. Los menoscabos a rueda de pozos, molinos, norias,

Juan, cit. (n. 133), p. 61].

${ }^{140}$ Fuero de Béjar, 130 [edición de Gutiérrez Cuadrado, Juan, cit. (n. 133), p. 61]. Si alguno de los vecinos no quería recibir el agua que procedía de manera natural de una finca ajena, debía pagar diez maravedís y el doble del daño ocasionado. Lo mismo se disponía en el Fuero de Sepúlveda, 153 [edición de Callejas, Feliciano, cit. (n. 122), p. 70].

${ }^{141}$ Fuero de Béjar, 205 [edición de Gutiérrez CuAdrado, Juan, cit. (n. 133), p. 70].

${ }^{142}$ Fuero de Béjar, 541 [edición de Gutiérrez Cuadrado, Juan, cit. (n. 133), p. 112; se comenta en p. 207].

${ }^{143}$ Fuero de Béjar, 196 [edición de Gutiérrez CuAdrado, Juan, cit. (n. 133), p. 69].

${ }^{144}$ Fuero de Béjar, 192 [edición de GutiérRez Cuadrado, Juan, cit. (n. 133), pp. 68-69]. Sobre la utilización del agua de los molinos para regar huertos cuando fuese necesario, véase: Fuero de Béjar, 206 [edición de Gutiérrez Cuadrado, Juan, cit. (n. 133), p. 70]. En cuanto a la construcción de nuevos molinos, canales artificiales para conducir agua, acequias o acueductos y la necesidad de puentes, consultar Fuero de Béjar, 186, 189, 190 y 191 [edición de Gutiérrez Cuadrado, Juan, cit. (n. 133), p. 68].

${ }^{145}$ Fuero de Béjar, 194 [edición de Gutiérrez CuAdrado, Juan, cit. (n. 133), p. 69].

${ }^{146}$ Fuero de Béjar, 187, 188 y 204 [edición de Gutiérrez Cuadrado, Juan, cit. (n. 133), pp. 68 y 70$]$. 
canales, baños o presa ajena se castigaban con pena de diez maravedís y el doble del perjuicio ocasionado ${ }^{147}$. El "quebrantar" un molino se equiparaba al quebrantamiento de casa y si se causaban daños se asimilaba al robo ${ }^{148}$. El incendio de molino ajeno se penalizaba con trescientos sueldos y el doble del daño cuando estaba probado, pero si se trataba de un incendio ocasional causado por el moledor solo debía reparar el deterioro ${ }^{149}$.

Cierta incidencia medioambiental, tendría la disposición del Fuero de Béjar que sancionaba al que hiciera sus necesidades en puerta ajena con dos maravedís y la obligación de limpiar lo que hubiese ensuciado, siempre que resultara probado salvo que demostrase lo contrario con un testigo ${ }^{150}$. Con cinco sueldos se castigaba echar estiércol o ensuciar las calles, siendo el almotacén el funcionario municipal encargado de velar por el cumplimiento de esta norma y de garantizar la limpieza de las calles ${ }^{151}$. El que tuviera letrina descubierta a la vista debía pagar cinco maravedís diarios hasta que la cubriese ${ }^{152}$. Cuando de la letrina se derivaban malos olores a la calle o a los vecinos, su propietario había de ser advertido y, si no lo evitaba en un plazo de tres días, tenía que pagar un maravedí diario hasta que solucionase el problema. Por este hecho, el almotacén podía tomar prendas y repartirlas con el demandante ${ }^{153}$.

El Fuero de Soria ${ }^{154}$ regulaba con detalle la protección de los montes y de las

${ }^{147}$ Fuero de Béjar, 200, 202 y 203 [edición de Gutiérrez Cuadrado, Juan, cit. (n. 133), pp. 69-70].

${ }^{148}$ Fuero de Béjar, 199 y 209 [edición de Gutiérrez CuAdrado, Juan, cit. (n. 133), pp. 69 y 70$]$.

${ }^{149}$ Fuero de Béjar, 197 y 198 [edición de Gutiérrez Cuadrado, Juan, cit. (n. 133), p. 69].

${ }^{150}$ Fuero de Béjar, 158 [edición de Gutiérrez Cuadrado, Juan, cit. (n. 133), p. 64]. En el Fuero de Sepúlveda hay una disposición similar pero se omite la obligación de limpiar lo ensuciado: Fuero de Sepúlveda, 162 [edición de Callejas, Feliciano, cit. (n. 122), p. 73].

${ }^{151}$ Fuero de Béjar, 548 [edición de Gutiérrez Cuadrado, Juan, cit. (n. 133), p. 113].

${ }^{152}$ Fuero de Béjar, 412 [edición de Gutiérrez Cuadrado, Juan, cit. (n. 133), p. 95 ].

${ }^{153}$ Fuero de Béjar, 413 [edición de Gutiérrez Cuadrado, Juan, cit. (n. 133), p. 95].

${ }^{154}$ Galo Sánchez sitúa el Fuero de Soria entre 1190 y 1214 y afirma que es anterior al Fuero Real al que ha servido de fuente, aunque hay quien señala, a su entender erróneamente, que lo concedió Alfonso X en 1256 [Fueros castellanos de Soria y Alcalá de Henares, edición y estudio de SÁnchez Sánchez, Galo (Madrid, Centro de Estudios Históricos, 1919), pp. 238-240]. Galo Sánchez utiliza para su edición del Fuero de Soria dos códices del siglo XIV, uno completo de la Biblioteca Nacional y otro incompleto conservado en el Ayuntamiento de Soria (pp. VII-XI). Para Rafael Gibert, es el Fuero Real la fuente del Fuero de Soria [Gibert, Rafael, El Derecho municipal de León y Castilla, en AHDE., 31 (1961), p. 734]. Gonzalo Martínez Díez sostiene que el Fuero de Soria es posterior al Fuero Real y ubica su redacción en el último cuarto del siglo XIII 
dehesas de Soria frente a extraños y vecinos ${ }^{155}$, incluyendo la prohibición de la caza, la pesca ${ }^{156}$, los incendios ${ }^{157}$ y la tala de árboles ${ }^{158}$. En cuanto a la pesca, se establecía la veda respecto a la trucha, desde el día de San Miguel hasta mediados de marzo, bajo pena de un maravedí, además de devolver lo pescado. Con esto se trataba de garantizar la reproducción. Si se pescaba de noche, con hacha o con veneno, con independencia de la época del año, se imponía una multa de dos maravedís y la devolución de la pesca ${ }^{159}$. En general, no se permitía pescar con red desde mediados de abril hasta San Miguel, siendo la sanción de cinco sueldos, la pérdida de la red y de la pesca, estando la cantidad económica destinada a aquél que descubriese esta acción ${ }^{160}$. Por otra parte, se contenía una minuciosa regulación sobre los daños a las "mieses" ${ }^{161}$, el cuidado de las viñas ${ }^{162}$, los daños a los

o principios del XIV [Martínez DíEz, Gonzalo, El Fuero de Soria: Génesis y fuentes, en $A H D E ., 76$ (2006), pp. 9-31]. Véase también: MARTínez DíEz, Gonzalo, El Fuero Realy el Fuero de Soria, en AHDE., 39 (1969), pp. 545-562]. De lo que no parece haber duda es de que el Fuero de Soria tiene como fuente al Fuero de Cuenca (año 1189 o 1190) [SÁnchez SÁnchez, Galo, cit., pp. 247-256 y Martínez Díez, Gonzalo, cit., pp. 24-26]. Consultar Pérez Martín, Antonio, El Fuero de Soria y el Derecho común, en $A H D E ., 76$ (2006), pp. 119-135.

${ }^{155}$ Fuero de Soria, $\$ \$ 1-40$ [edición de SÁnchez SánCheZ, Galo, cit. (n. 154), pp. 7-18]. Cfr. Fuero de Cuenca, I [edición de de Ureña y Smenjaud, Rafael, cit. (n. 111)]. De la guarda de los montes se ocupaban los “montaneros", según Fuero de Soria, $\$ \$$ 103-108 [edición de SánCHEZ SánCHEZ, Galo, cit. (n. 154), pp. 40-41].

${ }^{156}$ Fuero de Soria, $\$ \$ 13$ y 33 [edición de SÁnchez SáncheZ, Galo, cit. (n. 154), pp. 12 y 16].

${ }^{157}$ Fuero de Soria, $\$ 3$ [edición de Sánchez Sánchez, Galo, cit. (n. 154), p. 8].

${ }^{158}$ Fuero de Soria, $\$ \$ 4,9,30$ y 38 [edición de Sánchez Sánchez, Galo, cit. (n. $154)$, pp. $8,10,16$ y 18$]$.

${ }^{159}$ Fuero de Soria, $\$ 17$ [edición de SÁnchez SÁnchez, Galo, cit. (n. 154), pp. 12-13].

${ }^{160}$ Fuero de Soria, $\$ 18$ [edición de Sánchez Sánchez, Galo, cit. (n. 154), p. 13].

${ }^{161}$ Fuero de Soria, $\$ \$ 168-192$ [edición de SÁnCHEZ SánChEZ, Galo, cit. (n. 154), pp. 64-73]. Se presta atención al incendio, tanto intencionado como accidental, de las plantaciones sobre todo por el peligro que podría suponer su extensión por los potenciales daños. Véase Fuero de Soria, $\$ 183$ [edición de Sánchez Sánchez, Galo, cit. (n. 154), p. 70]. Cfr. Fuero de Cuenca, III, 21 y 22 [edición de de Ureña y Smenjaud, Rafael, cit. (n. 111)]. Respecto a la quema de rastrojos propios o ajenos, véase Fuero de Soria, $\$ 184$ [edición de SÁnchez SánCheZ, Galo, cit. (n. 154), p. 71] y Fuero de Cuenca, III, 24 [edición de De Ureña y SMenJaud, Rafael, cit. (n. 111)].

${ }^{162}$ Fuero de Soria, $\$ \$ 193-219$ [edición de Sánchez SÁnchez, Galo, cit. (n. 154), pp. 73-81]. Véase Fuero de Cuenca, IV [edición de DE UReña y Smenjaud, Rafael, cit. (n. 111)]. 
huertos ${ }^{163} \mathrm{o}$ a los prados $^{164}$, los molinos ${ }^{165}$ y los daños a los animales ${ }^{166}$.

Un capítulo completo dedicaba el Fuero de Soria al riego y a las aguas ${ }^{167}$. Por su parte, el de Cuenca incluía la mayoría de estas disposiciones en el capítulo relativo a los molinos ${ }^{168}$. Según el Fuero de Soria, si el agua de los molinos era necesaria para los huertos, prados o campos en general se debía entregar tres días a la semana (lunes, miércoles y viernes), desde el primero

${ }^{163}$ Fuero de Soria, $\$ \$ 220-234$ [edición de Sánchez SánChez, Galo, cit. (n. 154), pp. 81-86]. Aquí se incluía la tala de árboles y las penas dependían del tipo de árbol, de si era frutal o no y del lugar por donde se cortaba [Fuero de Soria, $\$ 229$ (edición de Galo Sánchez, p. 84)]. También se penalizaban los actos que provocaban que el árbol se secase: Fuero de Soria, $\$ 230$ [edición de Sánchez Sánchez, Galo, cit. (n. 154), pp. 84-85]. Véase Fuero de Alcalá de Henares, $\$ 241$ [edición de SÁnchez Sánchez, Galo, cit. (n. 154), p. 315] y Fuero de Cuenca, V, 12, 13, 14, 15 y 17 [edición de DE Ureña y SMENJaud, Rafael, cit. (n. 111)].

${ }^{164}$ Fuero de Soria, $\$ \$$ 235-236 [edición de SánCHEz SÁNCHEZ, Galo, cit. (n. 154), pp. 86-87].

${ }^{165}$ Fuero de Soria, $\$ \$$ 237-255 [edición de SÁnchez SÁnCHEZ, Galo, cit. (n. 154), pp. 87-92]. En esta materia, el Fuero de Soria coincide casi literalmente con el capítulo VIII del Fuero de Cuenca. En cuanto a la construcción de molinos, canales o presas se prescribía que los nuevos no podían afectar a los antiguos, en un sentido similar a lo que se disponía en el Fuero de Béjar o en el de Sepúlveda. Véase Fuero de Soria, $\$ \$ 239$, 240, 242 y 255 [edición de SÁnChez Sánchez, Galo, cit. (n. 154), pp. 87-88 y 92] y Fuero de Cuenca, VIII, 3, 4, 5, 6 y 18 [edición de De Ureña y Smenjaud, Rafael, cit. (n. 111)]. La regulación del Fuero de Soria, $\$ 244$ y del Fuero de Cuenca, VIII,8 es muy semejante a la examinada en el Fuero de Béjar, 192 en torno al problema de que los molinos situados abajo perjudicasen a los de arriba por exceso de agua, aunque la sanción prevista en el de Soria es inferior (dos maravedís diarios en lugar de los diez que establecían los otros fueros). Véase Fuero de Soria, $\$ 244$ [edición de SÁNCHEZ SÁNCHEZ, Galo, cit. (n. 154), pp. 88-89]. El incendio intencionado del molino ajeno se penalizaba con trescientos sueldos y el doble del daño; salvo que el fuego lo ocasionase el molinero de forma accidental, en cuyo caso solo debía indemnizar por los perjuicios. Cfr. Fuero de Soria, $\$ \$ 250$ y 251 [edición de SÁnchez SÁnchez, Galo, cit. (n. 154), p. 91] y Fuero de Cuenca VIII, 13 y 14 [edición de DE Ureña y SMenjaud, Rafael, cit. (n. 111)]. Lo mismo se establecía, como vimos, en el Fuero de Béjar, 197 y 198. Los daños a molinos, acequias, canales o presas, se sancionaban con una multa de diez maravedís. Vid. Fuero de Soria, $\$ \$ 252$ y 253 [edición de SÁncheZ SÁnChEZ, Galo, cit. (n. 154), p. 91] y Fuero de Cuenca, VIII, 15,16 y 17 [edición de DE Ureña y SMENJaUd, Rafael, cit. (n. 111)].

${ }^{166}$ Fuero de Soria, $\$ \$ 437$ y $442-454$ [edición de Sánchez Sánchez, Galo, cit. (n. 154), pp. 170-173]. Cfr. Fuero de Alcalá de Henares, $\$ \$ 211-218$ y 291 [edición de SÁnchez SÁnchez, Galo, cit. (n. 154), pp. 310-311 y 323] y Fuero de Cuenca, XXXVII, 4 y 5 [edición de DE UReÑa y SMEnJaud, Rafael, Cit. (N. 111)].

${ }^{167}$ Fuero de Soria, $\$ \$ 256-268$ [edición de SÁnchez SánCHEZ, Galo, cit. (n. 154), pp. 92-97]. La regulación es similar en el Fuero de Béjar.

${ }^{168}$ Fuero de Cuenca, VIII [edición de DE UREÑa y Smenjaud, Rafael, cit. (n. 111)]. 
de mayo hasta el quince de agosto y después, dos días a la semana (martes y viernes). Por su parte, el de Cuenca determinaba esta disponibilidad solo dos días a la semana (martes y viernes), con independencia de la época ${ }^{169}$. En cualquier caso, el agua siempre tenía que ser conducida por el lugar por donde los alcaldes entendiesen que causaba menos daños ${ }^{170}$. El Fuero de Soria especificaba el orden del riego; así, primero se regaban las huertas, seguidas de molinos, cáñamos, prados y por último, los restantes frutos, desde abajo hasta arriba, de forma que el agua llegase a todos los que la necesitasen. Si el agua era escasa, la siguiente vez comenzaba a regar el que había sufrido la mengua en la anterior ocasión y si era tan escasa que no llegaba a los molinos, se regaría durante el tiempo en que los molinos no estuviesen funcionando ${ }^{171}$. Los daños producidos por el riego se sancionaban con una multa de cinco sueldos y una indemnización por los perjuicios causados ${ }^{172}$. Pena idéntica se imponía al que cortase o tomase agua ajena o al que la vendía a otro ocasionando mengua a un tercero ${ }^{173}$. Todas las aldeas que tuviesen agua para el riego tenían que nombrar cada año dos "aguaderos", entre "los mayores" y "los mejores" hombres del pueblo que juraban sobre los Evangelios que iban a ejercer su oficio bien y lealmente. El nombramiento se hacía en la Pascua de Cuaresma. Entre sus funciones estaba controlar los turnos de riego, obligar

${ }^{169}$ Fuero de Cuenca, VIII, 19 [edición de De Ureña y Smenjaud, Rafael, CIT. (N. 111)].

${ }^{170}$ Fuero de Soria, $\$ 256$ [edición de SÁnchez SáncheZ, Galo, cit. (n. 154), pp. 92-93]. En cuanto al lugar por donde se debía llevar el agua y la sanción para los vecinos que se negaban a recibirla (un maravedí y la reparación del daño ocasionado), véase también Fuero de Soria, $\$ 261$ (pp. 94-95). Cfr. Fuero de Béjar, 130; Fuero de Sepúlveda, 153 (antes referidos) y Fuero de Cuenca, V, 6 y 7 [edición de DE UREÑa Y Smenjaud, Rafael, cit. (n. 111)].

${ }^{171}$ Fuero de Soria, $\$ 257$ [edición de SÁnchez SáncheZ, Galo, cit. (n. 154), pp. 93-94]. El vecino que no regaba en su turno tenía que esperar hasta el siguiente reparto y si no lo hacía y el agua no sobraba, debía pagar cinco sueldos e indemnizar al que había perjudicado. Cfr. Fuero de Soria, \$262 [edición de Sánchez Sánchez, Galo, cit. (n. 154), p. 95].

${ }^{172}$ Fuero de Soria, $\$ 259$ [edición de SÁnchez Sánchez, Galo, cit. (n. 154), p. 94]. Cfr. Fuero de Béjar, 127, ya analizado, y Fuero de Cuenca, V, 2 [edición de DE UREÑa y SMenjaud, Rafael, cit. (n. 111)]. Respecto a los daños ocasionados en finca ajena por el agua procedente de una presa, canal o molino, tanto en el Fuero de Soria como en el de Cuenca se prescribía lo mismo que en el Fuero de Béjar, 194, antes comentado. Véase Fuero de Soria, $\$ 263$ [edición de SÁnchez SÁnchez, Galo, cit. (n. 154), p. 95] y Fuero de Cuenca, VIII,10 [edición de DE UREÑa y SMENJaud, Rafael, cit. (n. 111)].

${ }^{173}$ Fuero de Soria, $\$ 260$ [edición de SÁnchez SÁnchez, Galo, cit. (n. 154), p. 94]. Véase Fuero de Béjar, 128, previamente referido, y Fuero de Cuenca, V, 3 [edición de De Ureña y Smenjaud, Rafael, cit. (n. 111)]. 
a la limpieza de las acequias y mediar en los conflictos vecinales ${ }^{174}$. El que no limpiase los límites de sus acequias debía abonar dos maravedís diarios hasta que lo hiciese ${ }^{175}$. Por motivos de higiene y salud pública y para garantizar la salubridad de las aguas, se prohibía que las mujeres lavasen cerca de las fuentes, bajo pena de cinco sueldos ${ }^{176}$.

Especial preocupación mostraba el Fuero de Andújar ${ }^{177}$ por la "guarda de los montes e de las aguas" ${ }^{\prime 17}$ y por la protección de la especie animal ${ }^{179}$, prohibiéndose la pesca con red barredera o trasmallo que se sancionaba con veinte maravedís ${ }^{180}$. Del mismo modo, se penalizaba la tala de vides ${ }^{181}$ y de árboles ${ }^{182}$ y los incendios ${ }^{183}$. Se regulaba la toma de agua para el riego velando por evitar daños y por su devolución, de manera similar a otros fueros ya analizados ${ }^{184}$. Se establecía la forma en la que se debían construir los molinos, presas, canales o acequias atendiendo a la distancia entre ellos y a la tradicional prohibición de que los nuevos ocasionasen perjuicios a los antiguos, siendo demolidos en tal

${ }^{174}$ Fuero de Soria, $\$ 264$ [edición de SÁNCHEZ SánCHEZ, Galo, cit. (n. 154), pp. 95-96].

${ }^{175}$ Fuero de Soria, $\$ 265$ [edición de SÁnchez Sánchez, Galo, cit. (n. 154), p. 96]. Cfr. lo que dijimos sobre Fuero de Béjar, 196 donde la sanción se imponía por semanas al igual que en el Fuero de Cuenca, VIII, 12: pectet duos aureos omni septimana [edición de DE UREÑa y SMENJAUd, Rafael, cit. (n. 111)].

${ }^{176}$ Fuero de Soria, $\$ 268$ [edición de SÁnChez Sánchez, Galo, cit. (n. 154), p. 96]. En cuanto a las fuentes y su limpieza, véase Fuero de Cuenca, VII,4 [edición de DE UREÑa y SMenJaud, Rafael, cit. (n. 111)].

${ }^{177}$ Véase el estudio sobre este fuero, su fecha y su relación con otros textos forales que realiza Martínez Llorente, Félix, La ciudad de Andújar y su Fuero. Un estudio histórico-jurídico, en Fuero de Andújar. Estudio y Edición (Andújar, Fundación Lázaro Galdiano, Pablo Quesada Huertas, Coordinador del Equipo de Investigación REVIPE, 2006), pp. 15-63. La edición y transcripción del fuero corre a cargo de GoNZÁLEZ Díez, Emiliano, pp. 67-249. Véanse las concordancias con el Fuero de Baeza y con el Fuero de Sabiote, en pp. 251-275. El facsímil se recoge en pp. 279-440.

${ }^{178}$ Fuero de Andújar, 663 [edición de GonZÁLEz DíEZ, Emiliano, cit. (n. 177), p. 236].

${ }^{179}$ Fuero de Andújar, 551, 552, 553, 554, 563, 566, 567, 568 y 569 [edición de GonzÁlez Díez, Emiliano, cit. (n. 177), pp. 209, 210, 211, 212, 213].

${ }^{180}$ Fuero de Andújar, 590 y 670 [edición de González DíEz, Emiliano, cit. (n. 177), pp. 215 y 238]. También se prohibía pescar con engaño, castigándose con la confiscación de bienes. Véase Fuero de Andújar, 663 [edición de González Díez, Emiliano, cit. (n. 177), p. 236].

${ }^{181}$ Fuero de Andújar, 85 [edición de GonZÁLEz DíEZ, Emiliano, cit. (n. 177), p. 100].

${ }^{182}$ Fuero de Andújar, 103, 104, 105 y 669 [edición de GonZÁlez DíEz, Emiliano, cit. (n. 177), pp. 103 y 237].

${ }^{183}$ Fuero de Andújar, 69, 70, 72, 111, 112, 626 y 669 [edición de GonZÁLEz DíEz, Emiliano, cit. (n. 177), pp. 97, 104, 227 y 237].

${ }^{184}$ Fuero de Andújar, 93, 94, 97 y 98 [edición de GonZÁlez DíEz, Emiliano, cit. (n. 177), pp. 101-102]. 
caso $^{185}$. Al igual que en el Fuero de Cuenca, se determinaba la disponibilidad del agua para el riego dos días a la semana (martes y viernes) y siempre debía tomarse del lugar donde menos daño provocase ${ }^{186}$. La salubridad del agua se garantizaba con la obligación de limpiar las acequias cuyo incumplimiento se multaba con dos maravedís semanales ${ }^{187}$. Asimismo, se ordenaba construir acequias en las aldeas y los señores en cuyas fincas estuviesen aquéllas tenían el deber de mantenerlas, repararlas y sanearlas y si no lo hacían perdían sus heredades que serían entregadas a otros pobladores que se comprometiesen a realizar las referidas tareas ${ }^{188}$.

También los Fueros de Usagre ${ }^{189}$ y Cáceres ${ }^{190}$ contenían disposiciones relacionadas con la materia ambiental, lo que ya se puede considerar como una constante en todos los fueros analizados. Se castigaba el incendio de monte o campo desde mayo hasta San Martín, es decir, en los meses de más calor, siempre que se ocasionasen daños ${ }^{191}$, y el de prado, viña, acequia, mo-

${ }^{185}$ Fuero de Andújar, 140, 141, 142, 143, 144 y 155 [edición de GonZÁlez Díez, Emiliano, cit. (n. 177), pp. 109-110 y 112]. También se recogía el problema de que los molinos situados abajo perjudicasen a los de arriba por exceso de agua o de que el agua procedente de presa, canal o molino provocase daños en heredad ajena, que veíamos en los Fueros de Béjar, Soria y Cuenca, adoptándose soluciones similares. Cfr. Fuero de Andújar, 145, 146 y 148 [edición de González Díez, Emiliano, cit. (n. 177), pp. 110-111]. Lo mismo se puede decir respecto al quebrantamiento y al incendio de molino y daños generales a molinos y presas: Fuero de Andújar, 151, 152, 153 y 154 [edición de GonzÁlez DíEz, Emiliano, cit. (n. 177), pp. 111-112].

${ }^{186}$ Fuero de Andújar, 156 [edición de González Díez, Emiliano, cit. (n. 177), p. 112].

${ }^{187}$ Fuero de Andújar, 150 [edición de González Díez, Emiliano, cit. (n. 177), p. 111]. Cfr. nota 175.

${ }^{188}$ Fuero de Andújar, 656 [edición de GonzÁlez DíEz, Emiliano, cit. (n. 177), p. 234].

${ }^{189}$ Fue otorgado a la villa de Usagre entre 1242 y 1275 [DE UREÑa y SMENJAUd, Rafael - Bonilla y SAN Martín, Adolfo, editores de Fuero de Usagre (siglo XIII). Anotado con las variantes del de Cáceres (Madrid, Hijos de Reus editores, 1907), p. XIII].

${ }^{190}$ Se concedió el 23 de abril de 1267 y sería confirmado el 12 de marzo de 1269 , aunque, según De Ureña, "el autor de esta noticia no determina como debiera, que esas fechas son de la Era hispánica, y que, por tanto, corresponden a los años 1229 y 1231" [de Ureña y Smenjaud, Rafael - Bonilla y San Martín, Adolfo, cit. (n. 189), p. XIV y nota 1 ].

${ }^{191}$ La pena era pecuniaria (diez maravedís y el doble del daño) y subsidiariamente, en caso de insolvencia, se aplicaba el talión (ser arrojado al fuego). Véase Fuero de Usagre, 3 y Fuero de Cáceres, 2 [edición de DE Ureña y SMenjaud, Rafael - BoniLla y SAN MARTín, Adolfo, cit. (n. 189), pp. 2-3, 199 y 217]. 
lino, huerto ajeno ${ }^{192}$ o el de casa extraña ${ }^{193}$, así como la quema de rastrojos ${ }^{194}$, la tala de árboles y viñas ${ }^{195}$, los perjuicios a éstas ${ }^{196} \mathrm{o}$ el arrojar estiércol a la calle, castillo, camino o zanja ${ }^{197}$ o cualquier cosa hedionda ${ }^{198}$. Se protegían especialmente las aves rapaces ${ }^{199} \mathrm{y}$ los animales en general ${ }^{200}$. El agua de una fuente que nacía entre dos heredades debía repartirse para el riego y todos los que la utilizasen estaban obligados a mantenerla limpia ${ }^{201}$. El funcio-

${ }^{192}$ En este caso, solo se imponía una pena pecuniaria de diez maravedís, además de la reparación del daño. Cfr. Fuero de Usagre, 108 y Fuero de Cáceres, 107 [edición de Ureña y Smenjaud, Rafael - Bonilla y San Martín, Adolfo, cit. (n. 189), pp. 40, 203 y 22]. En Fuero de Usagre, 171 y Fuero de Cáceres, 170, se indicaba que el que cortase o quemase viña ajena a sabiendas sería juzgado como "por morte de omme" [edición de de Ureña y Smenjaud, Rafael - Bonilla y San Martín, Adolfo, cit. (n. 189), pp. 64, 204 y 222].

${ }^{193}$ Fuero de Usagre, 165 y Fuero de Cáceres, 164 [edición de DE UREÑa y SMENJaUd, Rafael - Bonilla y SAn Martín, Adolfo, cit. (n. 189), pp. 62, 204 y 222].

${ }^{194}$ Fuero de Usagre, 162 y Fuero de Cáceres, 161 [edición de DE UREÑa Y SMENJAUd, Rafael - Bonilla y SAn Martín, Adolfo, cit. (n. 189), pp. 61, 204 y 222].

${ }^{195}$ Fuero de Usagre, 103 y Fuero de Cáceres, 102 [edición de DE UREÑa y SMENJaUd, Rafael - Bonilla y SAN Martín, Adolfo, cit. (n. 189), pp. 37-38, 202 y 220]. Véase también, en relación a la prohibición de la tala de árboles en el Fuero de Cáceres, pp. 190-191.

${ }^{196}$ Fuero de Usagre, 100 y Fuero de Cáceres, 99 [edición de DE UREÑa y SMENJAUd, Rafael - Bonilla y San Martín, Adolfo, cit. (n. 189), pp. 36-37, 202 y 220].

${ }^{197}$ La multa era un maravedí. Cfr. Fuero de Usagre, 163 y Fuero de Cáceres, 162 [edición de de Ureña y Smenjaud, Rafael - Bonilla y San Martín, Adolfo, cit. (n. 189), pp. 61, 204 y 222].

${ }^{198}$ Se especificaba que el que echase perro, cerdo o bestia muerta en la calle o en la ciudad tenía que pagar un maravedí, medio para el concejo y medio para los vecinos cercanos. Estos elementos malolientes debían ser arrojados a una distancia de diez estadales del foso o de la casa más alejada del barrio. Si se trataba de lechón, cachorro de perro, gato muerto o ave, la sanción era de cinco sueldos para los vecinos. Tampoco se podían quemar huesos, cuernos o cualquier otra cosa que ocasionase mal olor bajo multa de un maravedí. Véanse: Fuero de Usagre, 426 y Fuero de Cáceres, 476 [edición de de Ureña y Smenjaud, Rafael y Bonilla - San Martín, Adolfo, cit. (n. 189), pp. 149-150, 215 y 230].

${ }^{199}$ Fuero de Usagre, 6 y Fuero de Cáceres, 5 [edición de DE UREÑa y SMEnjaud, Rafael - Bonilla y San Martín, Adolfo, cit. (n. 189), pp. 3-4, 199 y 217].

${ }^{200}$ Fuero de Usagre, 19, 151, 152, 173, 174, 175, 286, 337 y 462 y Fuero de Cáceres, 20,150, 151, 172, 173, 174, 268, 318 y 420 [edición de DE UREÑa y SMENJAUd, Rafael - Bonilla y SAn Martín, Adolfo, cit. (n. 189), pp. 8, 56-57, 64-65, 104-105, 121, 163-164, 200, 204, 205, 208, 210, 213, 218, 222, 223, 226, 228 y 232].

${ }^{201}$ Fuero de Usagre, 159 y Fuero de Cáceres, 158 [edición de DE UREÑa y SMENJaud, Rafael - Bonilla y San Martín, Adolfo, cit. (n. 189), pp. 59-60, 204 y 222]. Esta misma disposición sancionaba el hurto del agua o la acción de impedir o entorpecer su curso con una multa de dos maravedís y el doble del agua. Sobre las fuentes, véase también Fuero de Usagre, 160 y Fuero de Cáceres, 159 [edición de DE UREÑA 
namiento de los molinos y acequias no podía privar de agua a los prados y huertos y, como en otros fueros, la construcción de un nuevo molino no debía perjudicar a los molinos más antiguos con independencia del lugar donde estuviesen situados ${ }^{202}$. La zona de pesca tenía que estar delimitada, por arriba y por abajo y el que pescase fuera con anzuelo o con buitrón era multado con tres maravedís ${ }^{203}$. Sin duda, incidía en la protección de las aguas frente a la contaminación la prohibición expresa de envenenar el río con hierbas bajo pena de cuatro maravedís ${ }^{204} \mathrm{o}$ la de que las mujeres lavasen en las fuentes del término de Usagre ${ }^{205}$.

En sentido similar, la prohibición de contaminar el agua de los ríos se contemplaba en el Fuero de Fuentes de la Alcarria ${ }^{206}$, castigándose con una pena pecuniaria de veinte maravedís la acción de arrojar veneno a un río, salvo que se pudiese probar lo contrario con dos testigos ${ }^{207}$. También se prohibía y se penalizaba con una multa el hecho de tirar estiércol, obligando, además, a la limpieza ${ }^{208}$.

La acción de "quebrantar" huerto, molino, era o monte de infanzón se castigaba con multa de sesenta sueldos en el Fuero Viejo de Castilla, ampa-

y Smenjaud, Rafael - Bonilla y San Martín, Adolfo, cit. (n. 189), pp. 60, 204 y 222].

${ }^{202} \mathrm{Si}$ el nuevo molino causaba daños al más antiguo, era derribado y se imponía al constructor una multa de cuatro maravedís, la mitad para el denunciante y la otra mitad para el alcalde. Cfr. Fuero de Usagre, 161 y Fuero de Cáceres, 160 [edición de de Ureña y Smenjaud, Rafael - Bonilla y SAn Martín, Adolfo, cit. (n. 189), pp. 60-61, 204 y 222].

${ }^{203}$ Fuero de Usagre, 161 y Fuero de Cáceres, 160 [edición de DE UREÑa y SMENJaud, Rafael - Bonilla y SAN Martín, Adolfo, cit. (n. 189), pp. 60-61, 204 y 222].

${ }^{204}$ Fuero de Usagre, 166 y Fuero de Cáceres, 165 [edición de DE UREÑA Y SMENJAUd, Rafael - Bonilla y SAn Martín, Adolfo, cit. (n. 189), pp. 62, 204 y 222].

${ }^{205}$ Fuero de Usagre, 255 y Fuero de Cáceres, 240 [edición de DE UREÑa y SMENJaud, Rafael - Bonilla y SAn Martín, Adolfo, cit. (n. 189), pp. 95, 207 y 223].

${ }^{206}$ Según Luis Vázquez de Parga este fuero sería concedido entre los años 1280 y 1299 por el arzobispo de Toledo Gonzalo Gudiel que fue quien hizo villa a Fuentes [VÁzQuez de Parga, Luis, Fuero de Fuentes de la Alcarria, en AHDE., 18 (1947), p. 6 de la separata].

${ }^{207}$ Fuero de Fuentes de la Alcarria, 178 [edición de VÁzQuez de PARGA, Luis, cit. (n. 206), p. 46]. En materia de aguas, véase también, respecto a los molinos: Fuero de Fuentes de la Alcarria, 60-62. Mayor número de artículos se dedicaban a la tala ilícita: Fuero de Fuentes de la Alcarria, 89, 94, 95, 96, 98, 102 y 185 [edición de VÁzQuEZ DE PARGA, Luis, cit. (n. 206), pp. 30-32 y 47] o a los daños a los animales: Fuero de Fuentes de la Alcarria, 142, 144, 145, 146, 147, 175 y 176 [edición de VÁzQuez de PARGa, Luis, cit. (n. 206), pp. 39-40 y 45]. En cuanto al incendio, consultar Fuero de Fuentes de la Alcarria, 90 [edición de Vázeuez de PArga, Luis, cit. (n. 206), p. 30].

${ }^{208}$ Fuero de Fuentes de la Alcarria, 209 [edición de VÁzQuez de PARGa, Luis, cit. (n. 206), p. 50]. 
rándose el derecho de propiedad ${ }^{209}$. Lo mismo se disponía en el "Pseudo Ordenamiento" II de Nájera ${ }^{210}$ y en el Fuero de los fijosdalgo y las fazañas del Fuero de Castilla ${ }^{211}$. Asimismo, se regulaba en estos cuerpos legales el daño a los animales y se sancionaba con multa variable, según la especie y según si se ocasionaba la muerte o solo una lesión ${ }^{212}$. Igualmente, se imponía pena pecuniaria a la tala ilícita de árboles ${ }^{213}$. En el Fuero Viejo y en el Libro de los Fueros de Castilla, estaba prohibido arrojar estiércol a un solar yermo $^{214}$. Sin embargo, no encontramos en los textos anteriores ninguna disposición relativa a la contaminación del agua ${ }^{215}$, sino solamente, en alguno

${ }^{209}$ Fuero Viejo de Castilla, I, 6, 1. Hemos manejado dos ediciones del Fuero Viejo: la de Los Códigos españoles concordados y anotados, cit. (n. 97), vol. I, ad casum, pp. 262263 y la de Alvarado Planas, Javier - Oliva Manso, Gonzalo, Los Fueros de Castilla. Estudios y edición critica del Libro de los Fueros de Castilla, Fuero de los fijosdalgo y las Fazañas del Fuero de Castilla, Fuero Viejo de Castilla y demás colecciones de fueros y fazañas castellanas (Madrid, Boletín Oficial del Estado, Centro de Estudios Políticos y Constitucionales, 2004), pp. 522-523.

210 "Pseudo Ordenamiento II de Nájera", 85 [edición de Alvarado Planas, Javier - Oliva Manso, Gonzalo, cit. (n. 209), p. 390].

${ }^{211}$ Fuero de los fijosdalgo y las fazañas del Fuero de Castilla, 62 [edición de AlvaRado Planas, Javier - Oliva Manso, Gonzalo, cit. (n. 209), pp. 436-437].

${ }^{212}$ Fuero Viejo de Castilla, II, 5,1,2 y 3; "Pseudo Ordenamiento II de Nájera", 57, 58 y 59 y Fuero de los fijosdalgo y las fazañas del Fuero de Castilla, 63, 103 y 104 [edición cit. (n. 97), vol. I, p. 276 (el Fuero Viejo) y edición de Alvarado Planas, Javier - Oliva Manso, Gonzalo, cit. (n. 209), pp. 553-554, 377, 437 y 447-448, respectivamente]. Se prestaba especial atención a las aves rapaces y a los perros. Según Jordano Fraga, la protección de las aves se hacía en función de su uso en cetrería [JoRDANo FrAGA, Jesús, cit. (n. 2), p. 25]. Lo mismo podría decirse de los perros respecto a la caza.

${ }^{213}$ Fuero Viejo de Castilla, II,5,4; Libro de los Fueros de Castilla, 54 y 161; "Pseudo Ordenamiento II de Nájera”, 106 y Fuero de los fijosdalgo y las fazañas del Fuero de Castilla, 72 [edición cit. (n. 97), I, p. 397 (el Fuero Viejo) y edición de Alvarado Planas, Javier - Oliva Manso, Gonzalo, cit. (n. 209), pp. 554, 277 y 309, 397 y 439, respectivamente].

${ }^{214}$ Fuero Viejo de Castilla, IV,4,8 y Libro de los Fueros de Castilla, 147 [edición cit. (n. 97), vol. I, p. 289 (el Fuero Viejo) y edición de Alvarado Planas, Javier - Oliva Manso, Gonzalo, cit. (n. 209), pp. 588 y 304-305, respectivamente].

${ }^{215}$ Sí que se regulaban problemas relacionados con el riego cuando el agua utilizada para regar debía pasar por fundos ajenos, exigiéndose el consentimiento del propietario, salvo que fuese costumbre: Fuero Viejo de Castilla, IV,4,3; "Pseudo Ordenamiento II de Nájera”, 108 y Fuero de los fijosdalgo y las fazañas del Fuero de Castilla, 107 [edición cit. (n. 97), vol. I, p. 288 (el Fuero Viejo) y edición de Alvarado Planas, Javier - Oliva Manso, Gonzalo, cit. (n. 209), pp. 586-587; 398 y 448-449, respectivamente]. Véase también, en cuanto a los conflictos para regar cuando el agua pasaba por dos heredades, Libro de los Fueros de Castilla, 144 [edición de Alvarado Planas, Javier - Oliva Manso, Gonzalo, cit. (n. 209), pp. 303-304]. Asimismo, se prohibían las obras que derivasen el agua de la lluvia a solares o casas ajenas ocasionando daños: Fuero Viejo de Castilla, IV, 5, 1; "Pseudo 
de ellos, una referencia indirecta a la limpieza de los cauces impuesta por la necesidad ${ }^{216}$. De nuevo, sería la propiedad lo que se tutelaba cuando no se permitía pescar en estanque o heredad ajena de día, penándose con sesenta sueldos de multa dirigidos al dueño de la finca y el doble de lo pescado, si se conseguía probar con dos testigos solventes. Si el hecho se cometía de noche se consideraba hurto ${ }^{217}$.

El Fuero Real prestaba mayor atención a la tala ilícita de los árboles ${ }^{218}$, a los daños (tala o incendio) en las viñas ${ }^{219}$, a la quema de "mieses" en ciertos lugares (era, casa o monte) donde se corría el riesgo de provocar un incendio ${ }^{220} \mathrm{o}$ a los

Ordenamiento II de Nájera", 87 y Fuero de los fijosdalgo y las fazañas del Fuero de Castilla, 31 [edición cit. (n. 97), vol. I, p. 289, en cuanto al Fuero Viejo y edición de Alvarado Planas, Javier - Oliva Manso, Gonzalo, cit. (n. 209), pp. 589, 391 y 429]. Sobre los molinos, véanse: Fuero Viejo de Castilla, IV,6 y Libro de los Fueros de Castilla, 40, 46, 79, 148, 150, 155 y 159 [edición cit. (n. 97), vol. I, p. 290 (Fuero Viejo) y edición de Alvarado Planas, Javier - Oliva Manso, Gonzalo, cit. (n. 209), pp. 591-593, 273-274, 275, $284,305,306,307$ y 308]. Si alguien quería construir un nuevo molino podía hacerlo siempre que no ocasionase perjuicios a otros molinos ni a heredades ajenas y si necesitaba repararlo estaba autorizado para cortar el agua a los demás durante doce o siete días, según el texto (Fuero Viejo de Castilla, IV,6,5 y Libro de los Fueros de Castilla, 148). Tampoco se podía construir una presa si se causaban daños a molinos más antiguos o a tierras ajenas. Esto se castigaba con una multa de cien sueldos al Rey, el doble del perjuicio al propietario afectado y la demolición de la obra para devolver la situación a su estado originario a costa del que ocasionaba el menoscabo (Fuero Viejo de Castilla, IV,6,6). La misma acción se sancionaba en el Libro de los Fueros de Castilla con cien maravedís y el doble del daño (Libro de los Fueros de Castilla, 150). Cualquier actuación en una presa o molino que interrumpiese el curso del agua y provocase perjuicios era penada con la reparación del daño y una multa (el doble del perjuicio al dueño del molino y sesenta sueldos al merino del Rey) siempre que se probase con "dos hombres buenos" (Fuero Viejo de Castilla, IV, 6, 7 y Libro de los Fueros de Castilla, 40 y 79).

${ }^{216}$ Fuero Viejo de Castilla, IV,5,5 [edición cit. (n. 97), I, p. 290 y edición de AlvARado Planas, Javier - Oliva Manso, Gonzalo, cit. (n. 209), p. 592].

${ }^{217}$ Fuero Viejo de Castilla, IV,5,8 [edición cit. (n. 97), I, p. 290 y edición de AlvaRado Planas, Javier - Oliva Manso, Gonzalo, cit. (n. 209), p. 593]. En el Libro de los Fueros de Castilla la pena era inferior ya que la pesca diurna se castigaba con sesenta sueldos y la devolución de lo pescado, sin exigirse prueba testifical. Cfr. Libro de los Fueros de Castilla, 112 [edición de Alvarado Planas, Javier - Oliva Manso, Gonzalo, cit. (n. 209), p. 292].

${ }^{218}$ Fuero Real, IV,4,2 [edición de Los Códigos españoles concordados y anotados, cit. (n. 97), I, p. 402]. La sanción era de tres maravedís por cada árbol si se trataba de frutales y dos si no lo eran. La multa se podía duplicar si el autor se llevaba el árbol cortado. Obviamente, se protegía directamente el derecho de propiedad y de manera indirecta el medio ambiente.

${ }^{219}$ Fuero Real, IV,4,3 [edición cit. (n. 97), I, p. 402]. Aquí se debía restituir al dueño el doble de lo dañado.

${ }^{220}$ Fuero Real, IV,5,11 [edición cit. (n. 97), I, p. 407]. En este caso, el autor era 
daños a los animales ${ }^{221}$ que a la salubridad de las aguas. No obstante, sí que se prohibía de manera expresa cerrar los ríos mayores que entraban en el mar, es decir, modificar su curso natural. La razón era de un lado, que se podían ocasionar perjuicios a las especies que en ellos habitaban y, en consecuencia, a la pesca; y de otro, que se impedía o dificultaba la navegación y el comercio fluvial. Sin embargo, si alguien era propietario de un fundo en la ribera de un río de tales características y necesitaba hacer una presa o molino estaba autorizado siempre que no afectase a las naves ni a los pescadores. La infracción de esta norma se sancionaba con una multa de treinta sueldos y con la obligación de deshacer la obra devolviendo la situación a su estado original ${ }^{222}$.

En las Partidas ${ }^{223}$ encontramos disposiciones relativas a la tala ilícita

castigado con el talión (ser quemado), aparte de pagar los perjuicios ocasionados y solamente con la reparación del daño si la quema era ocasional.

${ }^{221}$ Fuero Real, IV,4,1 y Fuero Real, IV,5,13 [edición cit. (n. 97), I, pp. 403 y 407].

${ }^{222}$ Fuero Real, IV,6,6 [edición cit. (n. 97), I, p. 408]. Comenta esta disposición Jesús Jordano Fraga quien señala que "responde a motivaciones de tipo económico", ya que "se dirige a impedir la destrucción del recurso natural de la pesca objeto de explotación, pero se impide al mismo tiempo la alteración de las condiciones del medio que lo sustentan, el curso del río, motivación esta a la que sí podemos calificar, al menos, de preambiental". A su entender, "la obligación de deshacer lo hecho" supone una superación del "enfoque estrictamente represivo, situándose el ámbito de acción de la norma en una esfera que podríamos denominar constructiva o positiva recogida por el Derecho ambiental moderno" [JoRdANO FraGa, Jesús, cit. (n. 2), pp. 23-24]. Nosotros observamos, en la prohibición de modificar el curso natural del río, el influjo del Derecho romano y la situación también estaba prevista en el Derecho islámico y, con mayor desarrollo y distinguiendo según la condición social a la hora de imponer sanciones, en el Derecho visigodo (recordemos $\mathrm{Li}$ ber Iudiciorum, VIII,4,29 y Fuero Juzgo, VIII,4,29).

${ }^{223}$ No podemos pasar por alto cierta inspiración ecologista en la regla del Derecho que conecta la libertad que deben garantizar los jueces con la naturaleza y el amor que por ella sienten no solo los hombres sino también los animales [Partidas, VII,34, regla $1^{a}$ [Las Siete Partidas del sabio rey don Alonso el Nono nuevamente glosadas por el licenciado Gregorio López del Consejo Real de Su Majestad (Salamanca, Andrea de Portonaris, 1555)]. 
de árboles, parras o viñas ${ }^{224} \mathrm{o}$ al incendio accidental ${ }^{225}$ que coinciden en lo esencial con las del Fuero Real ${ }^{226}$, aunque las penas se agravan. En relación a la tala, el espíritu de la ley incidiría no solo en motivos económicos o en la protección del derecho de propiedad sino también en el papel que los árboles desempeñan en el paisaje y el placer que proporcionan a la vista. Por tanto, tendría "más connotaciones ambientales" ya que se estaría tutelando "un valor de titularidad colectiva, consistente en el disfrute general de los mismos en cuanto bienes integrantes del entorno y del paisaje"227. Asimismo, se contemplaban los daños a los animales ${ }^{228}$. La acción de arrojar estiércol, agua (se supone que sucia) o huesos a la calle se castigaba solo cuando se ocasionaban daños en la ropa o en los paños de otro aunque se hiciera sin mala intención ${ }^{229}$. Por tanto, el fin último de la norma no era garantizar la higiene ni proteger el medio ambiente, ya que, en tal caso, se habría sancionado la acción en sí misma con independencia de que hubiese ocasionado un resultado dañoso.

En comparación a otros cuerpos legales, las Partidas dedicaban un mayor número de preceptos al agua y algunos sí que incidían en materia medioambiental, tal vez por influencia del Derecho romano. En principio,

${ }^{224}$ Partidas, VII,15,28. Se exigía la intencionalidad: “a mala intención”. La sanción genérica para cualquier tipo de menoscabo en árboles frutales o viñas ajenas era el doble del daño. Especial importancia se otorgaba si se trataba de vides o parras ya que el afectado podía optar por exigir la enmienda anterior o porque el autor del delito fuese perseguido como ladrón. En este último caso, si el daño era especialmente grave existía la posibilidad de aplicar la pena capital. Si era leve, correspondía al juez imponer una pena corporal a su libre albedrío según la entidad (tiempo y lugar) del perjuicio. Entiende Gregorio López que esta sanción se haría extensiva también a los árboles, sobre todo a los de "mayor estima" como los olivos y en función de su tamaño [LópEZ, Gregorio, glosa en vides o en parras y daño grande ad Partidas, VII,15,28, edición cit. (n. 223)]. Era lícita la tala de los árboles que se encontraban en las riberas de los ríos por parte del propietario de la heredad situada junto a esa ribera porque a él le pertenecían, salvo que alguien tuviese su nave amarrada a estos árboles utilizando el derecho común a usar las referidas riberas (Partidas, III,28,7).

${ }^{225}$ Partidas, VII, 15,10. Se castigaba al que, de manera imprudente, quemaba rastrojos o cualquier otra cosa, haciendo viento cerca de paja, madera, olivar o mies y ocasionaba un incendio, con la reparación de los daños causados.

${ }^{226}$ Cfr. Fuero Real, IV,4,2 y 3 y Fuero Real, IV,5,11, respectivamente.

${ }^{227}$ Jordano FraGa, Jesús, cit. (n. 2), p. 24, nota 14.

${ }^{228}$ Se regulaba de manera conjunta el daño a los siervos y a las bestias (Partidas, VII,15,15).

${ }^{229}$ Partidas, VII,15,25. La pena era el doble del daño y ascendía a cincuenta maravedís de oro cuando se producía un resultado de muerte, la mitad para los herederos del fallecido y la otra mitad para el fisco. La sanción se imponía de forma objetiva al que habitaba la casa con independencia de que fuese o no el propietario. Si había varios moradores todos eran responsables salvo que se supiese con certeza quien hizo el daño. 
se incluían entre las cosas susceptibles de aprovechamiento común ("cosas que comunalmente pertenecen a todas las criaturas") el agua de la lluvia y el mar, junto con su ribera y el aire y cualquiera podría hacer uso de ellos según su "menester" y sin límite alguno. Se especificaba que se podía utilizar el mar y su ribera navegando, pescando "e faziendo y todas las cosas que entendiere que a su pro son" ${ }^{230}$. No se decía nada respecto de las consecuencias de este uso, ni tampoco de la probable contaminación derivada del mismo. Incluso se permitían los edificios en la ribera del mar hasta el punto de que si éstos sufriesen daños a consecuencia de la acción del agua era posible volver a construirlos ${ }^{231}$. También los ríos, los puertos y los caminos públicos pertenecían a todos los hombres y cualquier persona podía utilizar las riberas de los ríos, aunque correspondiesen al propietario del predio en el que se encontraban ${ }^{232}$. Indica Gregorio López que, según lo dispuesto, sería "lícito a todos pescar en los ríos", aunque la ciudad bañada por dicho río, podría impedir la pesca a los extraños. Los argumentos esgrimidos son claramente medioambientales, dirigidos a la defensa de la riqueza piscícola y de las especies, ya que se trataba de evitar que los abusos a la hora de pescar (y también de cazar) redujesen la pesca (y la caza) y acabasen destruyéndola ${ }^{233}$. Es la navegación lo que se

${ }^{230}$ Partidas, III, 28, 3. Se sigue aquí el Derecho romano que consideraba el aire, el mar y el litoral como elementos comunes [D. 43,8,3 (Cels., 39 dig.)]. Cfr. Jordano FraGA, Jesús, cit. (n. 2), p. 16. En el mismo sentido, Espéculo, V, 8, 1 [edición de Los Códigos españoles concordados y anotados (Madrid, 1849), VI, p. 158]. Según Gregorio López, el Derecho de gentes no ha introducido ninguna variación en el Derecho natural primitivo, para el que todas las cosas son comunes. Remite a Alberico de Rociate para quien el uso de las cosas que se mencionan en la norma es común a todos los seres vivos, pero la facultad de adquirir el dominio que corresponde al primer ocupante, pertenece al Derecho de gentes [López, Gregorio, glosa a las criaturas ad Partidas, III,28,3, edición cit. (n. 223)].

${ }^{231}$ En este punto, entiende Gregorio López que debe tratarse de un edificio "construido lícitamente" y con autorización del Príncipe, ya que, de lo contrario, no habría sido posible su construcción ni adquirir su dominio. Refleja la opinión de Baldo degli Ubaldi en el sentido de que es lícito edificar en las playas cuando "no se perjudique el uso público". Por este motivo, estas construcciones deberían tener un carácter temporal [López, Gregorio, glosa que sea de alguno ad Partidas, III,28,3, edición cit. (n. 223)]. Sobre las cosas en general que se podían hacer en la ribera del mar, véase Partidas, III,28,4. Cfr. Espéculo, V,8,2 [edición cit. (n. 230), vol. VI, p. 158].

${ }^{232}$ Partidas, III,28,6. Aclara Gregorio López, siguiendo a Baldo, que los ríos son del "dominio particular de aquellas ciudades por cuyos territorios pasan" con independencia de que sean navegables, aunque, en general, pertenecen al Príncipe. Si un río pasa por dos ciudades, según Bartolo, será común a ambas [López, Gregorio, glosa los ríos ad Partidas, III,28,6, edición cit. (n. 223)].

${ }^{233}$ Añade que si alguien arrienda una laguna puede pescar en ella, pero si en la misma hubiese un "lecho" o "una porción de tierra elevada sobre el álveo donde se meten los peces en invierno", el arrendatario no podría abrir los lechos y tomar los peces ya que 
protegía cuando se prohibía construir un molino o cualquier otro edificio en un río, debiendo ser destruido si llegaba a levantarse ${ }^{234}$. La razón es que primaba la utilidad pública sobre el interés particular ${ }^{235}$.

El referido influjo del Derecho romano se observa cuando se establecía que una heredad inferior tenía derecho a recibir el agua de la superior de forma natural y, si sufría algún daño como consecuencia del movimiento del agua o porque descendiesen piedras o tierra, no se podía reclamar nada salvo que hubiese existido alguna intervención maliciosa ${ }^{236}$. Problema distinto era que el agua que discurría naturalmente por varias fincas se estancase como consecuencia de la acumulación de palos, piedras o cieno. Si esta situación causaba perjuicios a algún vecino, éste estaba facultado para exigir a aquél en cuya heredad se había estancado el agua que lo limpiase o que abriese de nuevo el curso $^{237}$. Pero si el lugar donde estaba el agua estancada era una acequia que pertenecía a varios, todos estaban obligados, en sus respectivos terrenos, a remediar la situación, ya que se trataba de una obra de interés común y,

con esto no estaría ejerciendo el derecho de pescar, sino que lo extinguiría, destruyendo la pesca [López, Gregorio, glosa pertenescen ad Partidas, III,28,6, edición cit. (n. 223)]. En el Espéculo se recogían las formas de pescar y se prescribía que había de hacerse de modo que no se ocasionase menoscabo en "las rendas de los pescados": Espéculo, V,8,2 [edición cit. (n. 230), VI, p. 158]. Sobre la prohibición de cazar algunas especies, véase: Espéculo, V,8,6 [edición cit. (n. 230), vol. VI, p. 160].

${ }^{234}$ Partidas, III,28,8. Precisa Gregorio López que también estará prohibido desviar el agua de un río no navegable, si éste se une con otro que sí lo sea. Pero, según Bartolo, la prohibición solo será aplicable cuando, a consecuencia de la desviación, el agua ya no vuelve a entrar en el río navegable. En caso contrario, sí se podrá desviar [López, Gregorio, glosa con sus navios ad Partidas, III,28,8, edición cit. (n. 223)]. Asimismo, se prohibía construir un molino que alterase el curso ordinario del agua impidiendo su uso por los demás (Partidas, III,32,18). Sin embargo, cualquiera podía abrir un pozo o una fuente en su heredad, aprovechando el agua del vecino siempre que no se hiciera maliciosamente con intención de interrumpir o menguar el agua de éste o con engaño, porque, en tal caso, se podría impedir, derribar o cerrar (Partidas, III,32,18).

${ }^{235}$ López, Gregorio, glosa el pro de todos ad Partidas, III,28,8, edición cit. (n. 223).

${ }^{236}$ Partidas, III,32,14. Gregorio López plantea el problema de que el agua que discurre de forma natural perjudique de manera excesiva al predio vecino situado en la parte inferior. En este caso, Paolo de Castro sostiene que se podría ejercer alguna acción para "apartar el agua”. Sin embargo, según Alberico de Rociate habría que soportar los daños aunque sean inmensos y el propietario del campo inferior solo podría levantar terraplenes en el superior para minimizar los perjuicios [LópEz, Gregorio, glosa natural ad Partidas, III,32,14, edición cit. (n. 223)].

${ }^{237}$ Partidas, III,32,15. Aclara Gregorio López, siguiendo a Bartolo, que esto solo tendrá lugar cuando aquél en cuya finca se ha estancado el agua va a obtener algún beneficio de la limpia, ya que, en caso contrario, solo se le podrá obligar a que tolere la limpieza o reparación de la acequia, pero no a que lo haga él mismo [López, Gregorio, glosa de dos cosas la una ad Partidas, III,32,15, edición cit. (n. 223)]. 
por tanto, había de realizarse a expensas de los que iban a aprovecharse de la $\mathrm{misma}^{238}$. Si el estancamiento era consecuencia de alguna obra hecha por un propietario en su heredad y ocasionaba daños a otro, éste tenía el derecho a exigir que dicha obra fuese derribada ${ }^{239}$.

Por otra parte, el que tuviese una servidumbre en un predio ajeno para conducir agua por él debía mantener el cauce, acequia, canal o caño por donde pasase el agua de forma que no podía modificarlo ni causar daño al propietario $^{240}$. Entendemos que en el mantenimiento irían incluidas las tareas de reparación necesarias y la limpieza ${ }^{241}$. Cuando alguien tenía una servidumbre que le permitiese tomar agua de una fuente situada en heredad ajena para regar sus tierras debía prestar su consentimiento para que el dueño del predio concediese a otro el derecho a utilizar el agua ${ }^{242}$.

Mayor repercusión ambiental tendría la disposición, también inspirada en el ordenamiento jurídico romano, atinente a la reparación y limpieza de las acequias y cañerías, tanto de las casas como de heredades, que debía quedar garantizada aunque esta actividad causase mal olor a los vecinos u otras molestias derivadas de la misma como la presencia de piedras, ladrillos o tierra.

${ }^{238}$ Partidas, III,32,15. Cfr. López, Gregorio, glosa cada uno ad Partidas, III, 32, 15, edición cit. (n. 223).

${ }^{239}$ Partidas, III,32,16. Lo que la norma plantea es el problema de la legitimidad en caso de que una finca u otra haya sido vendida antes de que se entablasen las correspondientes acciones. Véase también: Partidas, III,32,17 donde se aborda la legitimación activa y pasiva para ejercer la demanda cuando una obra nueva ocasionaba una interrupción o pérdida de agua y había varios responsables y varios afectados. En cuanto a la denuncia de la obra nueva que causaba perjuicios y la posibilidad de adoptar medidas cautelares suspendiendo dicha obra, cfr. Partidas, III,32,9.

${ }^{240}$ Partidas, III, 31, 4. Puntualiza Gregorio López, citando a Azzo, que el acueducto es "el derecho de conducir el agua por el fundo ajeno" [López, Gregorio, glosa por do pasan aguas ad Partidas, III,31,4, edición cit. (n. 223)]. Es decir, la servidumbre de acueducto sería la facultad de un particular de atravesar tierras ajenas para llevar el agua de un río o de un canal a su propia finca y se debía hacer sin causar daños, para lo cual se adoptaban las oportunas medidas. Sobre el origen de la institución del acueducto forzoso, véase D’Ors, Álvaro, Parerga Histórica (Pamplona, Eunsa, 1997), pp. 239-270.

${ }^{241}$ Así, indica Gregorio López que "aquel a quien se debe la servidumbre, está obligado a rehacer y limpiar las acequias por donde pasa el agua”. Si el acueducto era público la obligación de limpieza correspondería a todos los poseedores de las tierras por donde pasase de manera proporcional [López, Gregorio, glosa el cauze ad Partidas, III,31,4, edición cit. (n. 223)].

${ }^{242}$ Partidas, III,31,5. Los pozos, canales, acueductos y caños de un predio y todo lo que estuviese a su servicio, tanto dentro como fuera del mismo, se transmitían con éste (Partidas, V,5,28). Sobre la forma de adquirir estas servidumbres por el uso y el paso del tiempo, véase: Partidas, III,31,15 y respecto a la transmisión de la servidumbre de agua, Partidas, III,31,12. En cuanto a cómo se debían usar estas servidumbres para beber tanto las personas como el ganado, consultar Partidas, III,31,6. 
Es decir, a pesar de los inconvenientes, nadie podía impedir estos trabajos porque redundaban en beneficio de las propias casas (que de lo contrario podrían sufrir muchos daños hasta el punto de tener que ser derribadas) y, por ende, de la ciudad, y favorecían la salud de la población por la que habría que velar ante todo, ya que las emanaciones como consecuencia de la falta de saneamiento resultaban nocivas. En cualquier caso, los que realizasen estas tareas de limpieza tenían que cuidar que todo quedase como antes una vez concluidas y que no perjudicasen los derechos de los demás ${ }^{243}$. Obviamente, aquí los intereses colectivos relacionados con la higiene, la seguridad y la salud pública se encontraban por encima de los intereses particulares que pudieran verse afectados por estas actividades. Sin embargo, quedaban prohibidas las obras para canalizar el agua de la lluvia o impedir o modificar el curso normal del agua si perjudicaban a los vecinos, causando daños materiales en sus fincas o menoscabando u obstaculizando el uso del agua para el riego por parte de éstos. Cualquiera de estas obras sería demolida a costa del que la hizo, devolviendo la situación a su estado originario e indemnizando por los perjuicios ocasionados ${ }^{244}$. Asimismo, incidía en el interés general la obligación de mantener y reparar, entre otros bienes públicos, las fuentes, puentes, caños y acueductos a la que todos tenían que contribuir aunque inicialmente perteneciesen al Rey ${ }^{245}$.

${ }^{243}$ Partidas, III,32,7. Recordemos que el Derecho romano prohibía que se tratase de impedir violentamente la limpieza y reparación de acequias, canales cubiertos, o presas por las que discurría el agua [D. 43,21,1 pr. (Ulp., 70 ad ed.)], haciéndose extensiva dicha prohibición a las fuentes [D. 43,22,1,6,7 y 8 (Ulp., $70 \mathrm{ad}$ ed.)], pozos, lagos y piscinas [D. 43,22,1,10 (Ulp., 70 ad ed.)]. En cuanto a las cloacas, tampoco se podía impedir su reparación y limpieza en aras de la salud pública. Véase lo que dijimos sobre D. 39,1,5,11 (Ulp., 52 ad ed.), D. 43,23,1,2 (Ulp., 71 ad ed.) y D. 43,23,1,7 (Ulp., 71 ad ed.). Gregorio López hace extensiva esta disposición no solo a la limpieza y reparación de los caños y acequias sino también a la construcción de otros nuevos [López, Gregorio, glosa reparando ad Partidas, III,32,7, edición cit. (n. 223)]. Recoge el pensamiento de Alberico de Rosciate en el sentido de que "es una verdad reconocida en medicina, que es peor el mal olor, que la mala comida” [López, Gregorio, glosa mal olor ad Partidas, III,32,15, edición cit. (n. 223)].

${ }^{244}$ Partidas, III,32,13. Véase lo que apuntamos sobre la actio aquae pluviae arcendae. También estaba prevista esta situación en el Derecho islámico. Indica Gregorio López, remitiendo a Paolo de Castro, que si alguien, mediante una obra, desviaba de su finca el agua de la lluvia, para que no le ocasionase daño, si no existía de otra parte una servidumbre particular que le forzase a recibirla, ni lo establecían los estatutos municipales, obraría lícitamente, "y no le obligaría lo prevenido en esta ley, aun cuando causase con ello algún perjuicio al vecino” [López, Gregorio, glosa derribad a su costa ad Partidas, III,32,13, edición cit. (n. 223)].

${ }^{245}$ Partidas, III,32,20. En cuanto a los puentes, se pregunta Gregorio López cuáles serían los vecinos obligados a la construcción o rehabilitación de los mismos, recurrien- 


\section{BiBLIOGRAFÍA}

Alvarado Planas, Javier y Oliva Manso, Gonzalo, Los Fueros de Castilla. Estudios y edición critica del Libro de los Fueros de Castilla, Fuero de los fijosdalgo y las Fazañas del Fuero de Castilla, Fuero Viejo de Castilla y demás colecciones de fueros y fazañas castellanas (Madrid, Boletín Oficial del Estado, Centro de Estudios Políticos y Constitucionales, 2004).

Álvarez Llopis, Ma Elisa, Molinos hidráulicos en Cantabria, siglos X al XIII, en El Fuero de Santander y su época. Actas del Congreso conmemorativo de su VIII centenario (Santander, Diputación regional de Cantabria, Ayuntamiento de Santander, Universidad de Cantabria, Ediciones de Librería Estvdio, 1989).

AllaRD, Georges, Législation romaine sur les eaux (tesis doctoral, Lille, Imprimerie L. Danel, 1874).

BALlenegger, Jacques, La pollution en droit international: la responsabilité pour les dommages causés par la pollution transfrontière (Lausanne, Imprimerie Vaudoise, 1975).

Betancourt, Fernando, Derecho romano clásico (4a edición revisada y aumentada, Sevilla, Universidad de Sevilla, 2010).

Betancourt, Fernando, El Libro anónimo “de interdictis". Codex Vaticanus Latinus, $n^{\circ} 5766$ (Sevilla, Universidad de Sevilla, Secretariado de Publicaciones, 1997).

BIONDI, Biondo, Istituzioni di diritto romano (Milano, Giuffrè, 1946).

Bonfante, Pietro, Istituzioni di diritto romano ( $10^{a}$ edición, Torino, Giappichelli, 1946).

Bonfante, Pietro, Las relaciones de vecindad (traducción, prólogo, concordancias y apéndice de Alfonso García Valdecasas, Madrid, Reus, 1932).

Boscheron, Achille, Babylone et la Bible. Code de Hammourabi et Livre de L'Alliance (Caen, Imprimerie Charles Valin, 1906).

do, entre otros, a Alberico de Rosciate quien advertía que "la vecindad se hace extensiva para los efectos de dicha ley a todos aquellos a cuyas casas hubiese podido temerse verosímilmente que se extendiese el incendio, cuya determinación se deja al arbitrio del juez" [López, Gregorio, glosa las puentes ad Partidas, III,32,20, edición cit. (n. 223)]. Problema distinto era si el vecino que renunciaba al uso del agua o de la fuente, tenía que contribuir a su reparación. Aquí habría que distinguir si el acueducto o fuente había sido inutilizado por la acción de algún hombre, en cuyo caso sería éste el obligado a repararlo, o por un vicio de la construcción, correspondiendo entonces la reparación al constructor en un periodo de treinta años o de quince si la culpa no estaba probada. Si la ruina se debía a terremoto o accidente similar y se trataba de aguas que servían para el riego cualquier vecino podía eximirse del impuesto para la restauración, si abandonaba las propiedades que se beneficiaban con dicho riego. Sin embargo, si se trataba de agua potable, difícil de encontrar en otro sitio, no se admitiría ninguna renuncia, salvo que el renunciante fuese pobre y siempre que la fuente o acueducto no se hubiese inutilizado con el uso de los que habían sacado o disfrutado el agua; pues, en tal supuesto, estarían obligados a contribuir por razón de hechos pasados y no debían ser oídos, aunque estuviesen dispuestos a renunciar a su derecho en lo sucesivo, siendo en todo caso aplicable el arbitrio del juez [López, Gregorio, glosa por lo que ouiere ad Partidas, III,32,20]. 
BRUNs, K. G., Fontes iuris romani antiqui (7a edición, Tübingen, 1909, reedición, Scientia Verlag Aalen, 1969).

Bussi, Emilio, La formazione dei dogmi di diritto privato nel diritto comune. Diritti reali e diritti di obbligazione (Padova, Cedam, 1937)

Cancio Meliá, Manuel - Jorge Barreiro, Agustín (coordinadores), Estudios sobre la protección penal del medio ambiente en el ordenamiento jurídico español (Granada, Comares, 2005).

Canosa Usera, Raúl, Constitución y medio ambiente (Madrid, Dykinson, 2000).

Cantero Cerquella, Cristóbal Javier, La responsabilidad penal de los funcionarios por delitos ambientales (con "Prólogo" de Agustín Jorge Barreiro y Manuel Cancio Meliá, Madrid, Reus, 2010).

Carrasco, Pilar, Estudio Lingüistico del Fuero de Zamora (Málaga-Salamanca-Zamora, Universidad de Málaga, Universidad de Salamanca y Colegio Universitario de Zamora, 1987).

Cavanilles, Antonio, Memoria sobre el Fuero de Madrid de 1202, en Memorias de la Real Academia de la Historia (Madrid, 1852), tomo VII, en http://www.biblioteca. org.ar/libros/70165.pdf].

Cerdá Ruiz-Funes, Joaquín, Características histórico-jurídicas de los riegos, en El Libro de la Huerta de Murcia (Ayuntamiento de Murcia, 1973) = Estudios sobre instituciones jurídicas medievales de Murcia y su Reino (Academia de Alfonso X el Sabio, Murcia, 1987).

Cicerón, Marco Tulio, Las leyes (traducción, introducción y notas por Álvaro d'Ors, Madrid, Instituto de Estudios Políticos, 1970).

Codex Iustinianus (en Corpus Iuris Civilis (edición de Krueger, Paul, $11^{\text {a }}$ edición, Berlin, 1954 y reedición anastática, Hildesheim, Weidmann, 1997), II.

Codex Theodosianus (edición de Mommsen, Theodor y Krueger, Paul, reedición anastática, Hildesheim, Weidmann, 1990).

Corán (edición preparada por Cortés, Julio, $5^{\text {a }}$ edición revisada, Barcelona, Herder, 1995).

Costa, Emilio, Le acque nel Diritto romano (Bologna, Nicola Zanichelli editore, 1919).

Coulson, Noel J., Historia del Derecho islámico (traducción de María Eugenia Eyras, Barcelona, edicions Bellaterra, 1998).

Dareste de la Chavanne, Rodolphe, Le Code babylonien d'Hammourabi, en Nouvelle Revue Historique de Droit Français et Étranger, 27 (1903).

Dareste de la Chavanne, Rodolphe, Nouvelles études d'histoire du droit (Paris, Librairie de la Société du Recueil J.-B. Sirey \& du Journal du Palais. Ancienne Maison L. Larose \& Forcel, 1906).

De Diego Velasco, María Teresa, Las Ordenanzas de las Aguas de Granada, en En la España Medieval, 4 (1984).

de Ureña y Smenjaud, Rafael - Bonilla y San Martín, Adolfo (editores), Fuero de Usagre (siglo XIII). Anotado con las variantes del de Cáceres (Madrid, Hijos de Reus editores, 1907).

De Ureña y Smenjaud, Rafael, Fuero de Cuenca (formas primordial y sistemática: texto latino, texto castellano y adaptación del Fuero de Iznatoraf) (Madrid, 1935), en http://www.uclm.es/ area/dromano/CR/fuerol.htm].

Declaración de la Conferencia de las Naciones Unidas sobre el Medio Ambiente humano de Estocolmo (5-16 de junio de 1972). 
Delzons, Hector, De aqua et aquae pluviae arcendae (tesis de licenciatura, Paris, Imprimerie de A. Henry, 1844).

DI Porto, Andrea, La tutela della "salubritas" fra editto e giurisprudenza, I: Il ruolo di Labeone (Milano, Giuffrè, 1990).

Digesta. Edición de Mommsen, Theodor - Krueger, Paul, Corpus Iuris Civilis (13 edición, Berlin, Apud Weidmannos, 1920), I].

Domingo, Rafael, Textos de Derecho romano (Cizur Menor, Aranzadi, 2002).

Escobar RocA, Guillermo, La ordenación constitucional del medio ambiente (Madrid, Dykinson, 1995).

Fedeli, Paolo, La natura violata. Ecologia e mondo romano (Palermo, Sellerio, 1990).

Federovisky, Sergio, Historia del medio ambiente (Buenos Aires, editorial Capital Intelectual, 2007).

Fernández Gimeno, José Pascual - Gamborino Martínez, Gloria, en Reyes López, María José (coordinadora), Derecho ambiental español (Valencia, Tirant lo Blanch, 2001).

Formulario notarial hispano-árabe, por el alfaqui y notario cordobés Ibn Al-'Attār (edición de Chalmeta, Pedro y Corriente, F., Madrid, Academia Matritense del Notariado-Instituto Hispano-Árabe de Cultura, 1983).

Frontino, De aquaeductu urbis Romae (edición de Krohn, F., Leipzig, 1922).

Fuero de Salamanca, con notas, apéndice y un discurso preliminar de SÁNCHEZ RuANo, J. (Salamanca, Imprenta de Sebastián Cerezo, 1870).

Fuero de Sepúlveda, en Boletín de Jurisprudencia y Administración y arreglado y anotado por Callejas, Feliciano (Madrid, Imprenta del Boletín de Jurisprudencia, 1857).

Fueros castellanos de Soria y Alcalá de Henares, edición y estudio de Sánchez Sánchez, Galo (Madrid, Centro de Estudios Históricos, 1919).

García Quintas, María de las Mercedes, Algunas implicaciones jurídicas de la conducción del agua a la Roma Antigua, en Anuario Jurídico y Económico Escurialense, 44 (2011).

García SÁnChez, Justo, Teoría de la immissio (Madrid, 1975; 1ª reimpresión, Oviedo, 1979; 2a reimpresión, Oviedo, Servicio de Publicaciones de la Universidad de Oviedo, 1999).

García Ureta, Agustín (coordinadores), Estudios de Derecho ambiental europeo (Bilbao-Pamplona, ed. Pamiela, 2006).

Gerez Kraemer, Gabriel M., El derecho de aguas en Roma (Madrid, Dykinson, 2008).

Gibert, Rafael, El Derecho municipal de León y Castilla, en AHDE., 31 (1961).

GirARD, Paul Frédéric, Manuel élémentaire de droit romain ( $4^{\mathrm{a}}$ edición, Paris, Arthur Rousseau éditeur, 1906).

Gómez Rojo, María Encarnación, Precedentes de protección medioambiental en el Derecho Histórico Español de la Edad Moderna, en Arancibia MatTAR, Jaime MARTínez Estay, José Ignacio (coordinadores), La primacía de la persona. Estudios en homenaje al Profesor Eduardo Soto Kloss (Santiago de Chile, LegalPublishing, AbeledoPerrot, 2009).

Gómez Royo, Enrique, El régimen de las aguas en las relaciones de vecindad en Roma (Valencia, Tirant lo Blanch, 1997).

González de Molina, Manuel, Historia y medio ambiente (Madrid, Eudema, 1993). 
Gutiérrez Cuadrado, Juan, Fuero de Béjar (Salamanca, Universidad de Salamanca, 1974).

Hurtado de Molina Delgado, Julián, Delitos y penas en los fueros de Córdoba y Molina (Córdoba, Servicio de Publicaciones de la Universidad de Córdoba-Ilustre Sociedad Andaluza de Estudios Histórico-Jurídicos, 2003).

Iglesias, Juan, Derecho romano (17 a edición, Barcelona, Ariel, 2008).

Jaquenod Martínez, Silvia Susana, El Derecho ambiental y sus principios rectores (Madrid, Universidad Complutense, 1989),

Jiménez SALCEDo, $\mathrm{M}^{\mathrm{a}}$ Carmen, El régimen jurídico de las relaciones de vecindad en Derecho romano (con "Prólogo" de Antonio Fernández de Buján, Córdoba, publicaciones de la Universidad de Córdoba y Obra Social y Cultural Cajasur, 1999).

Jordano Fraga, Jesús, La protección del derecho a un medio ambiente adecuado (Barcelona, Bosch, 1995).

Kiss, Alexandre - Shelton, Dinah, A Guide to International Environmental Law (Leiden-Boston, Martinus Nijhoff publishers, 2007).

Kiss, Alexandre - Shelton, Dinah, Manual of European Environmental Law (2a edición, Cambridge, Grotius, 1997).

Droit international de l'environnement KRÄMER, Ludwig, Derecho ambientaly Tratado de la Comunidad Europea (traducción de la $3^{\text {a }}$ edición de Luciano Parejo Alfonso y Ángel Manuel Moreno Molina, Madrid, Marcial Pons, 1999).

Lara Peinado, Federico (Madrid, 1982).

Las Siete Partidas del sabio rey don Alonso el Nono nuevamente glosadas por el licenciado Gregorio López del Consejo Real de Su Majestad (Salamanca, Andrea de Portonaris, 1555).

Liber iudiciorum en Los Códigos españoles concordados y anotados (Madrid, Imprenta de la publicidad, 1847), I.

López Ortiz, José, Derecho musulmán (Barcelona-Buenos Aires, Labor, 1932).

Lozano Cutanda, Blanca - Alli Turrillas, Juan Cruz, Administracióny legislación ambiental ( $5^{\text {a }}$ edición, Madrid, Dykinson, 2009).

Lozano Cutanda, Blanca, Derecho ambiental administrativo (9a edición, Madrid, Dykinson, 2008; $11^{\text {a }}$ edición, Madrid, La Ley, 2010).

Luluín Bergareche, Raquel, Mecanismos jurídicos civiles de tutela ambiental (Navarra, Aranzadi, 2005)

LlodrÀ Grimalt, Francesca, Lecciones de Derecho ambiental civil (Palma, Universitat de les Illes Balears, 2008).

Mandirola Brieux, Pablo, Introducción al Derecho islámico (Madrid-Barcelona, Marcial Pons, 1998).

Martínez Almira, Ma Magdalena, Derecho de Aguas. Malos usos y contaminación en el Derecho andalusi, en AHDE., 76 (2006).

Martínez Díez, Gonzalo, El Fuero de Soria: Génesis y fuentes, en AHDE., 76 (2006).

Martínez Díez, Gonzalo, El Fuero Real y el Fuero de Soria, en AHDE., 39 (1969).

Martínez Llorente, Félix, La ciudad de Andújar y su Fuero. Un estudio históricojurídico, en Fuero de Andújar. Estudio y Edición (Andújar, Fundación Lázaro Galdiano, Pablo Quesada Huertas, Coordinador del Equipo de Investigación REVIPE, 2006).

Martos Nuñez, Juan Antonio [et alii], Derecho penal ambiental (Madrid, Exlibris, 
2006) y Martos NuÑEz, Juan Antonio, El delito de contaminación acústica (Madrid, Iustel, 2010).

Martos Quesada, Juan, Introducción al mundo jurídico de la España musulmana (Madrid, Ediciones G. Martín, 1999).

Matellanes Rodríguez, Nuria, Derecho penal del medio ambiente (Madrid, Iustel, 2008).

Mendo Estrella, Álvaro, El delito ecológico del artículo 325.1 del Código Penal (Valencia, Tirant lo Blanc, 2009).

Mercier de Lacombe, Auguste St. Hilaire, De la propiété comunale. Des interdits de aqua quotidiana et aestiva, de rivis, de fonte (tesis doctoral, Paris, 1856).

Montemayor Aceves, Martha Elena (México, Universidad Nacional Autónoma de México, 1994).

Moreno Molina, Ángel Manuel, Derecho comunitario del medio ambiente, marco institucional, regulación sectorial y aplicación en España (Madrid, Marcial Pons, 2006).

Muñoz y Romero, Tomás, Colección de Fueros Municipales y Cartas Pueblas de los reinos de Castilla, León, Corona de Aragón y Navarra (Madrid, 1847; reedición anastática, Madrid, Imprenta de Don José María Alonso, 1972).

Pérez Martín, Antonio, El Fuero de Soria y el Derecho común, en AHDE., 76 (2006).

Planitz, Hans, Principios de Derecho privado germánico (traducción de la $3^{\text {a }}$ edición alemana de Carlos Melón Infante, con "prólogo" de Alfonso García Gallo, Barcelona, Bosch, 1957).

Ponte Iglesias, María Teresa, La contaminación fluvial: cuestiones de responsabilidad internacional (Santiago de Compostela, Xunta de Galicia, Consellería da Presidencia e Administración Pública, Servicio Central de Publicacions, 1989).

Ponte, V. Régimen jurídico de las víaspúblicas en Derecho Romano (Madrid, Dykinson, 2007).

Proudhon, M. Traité du domaine public, ou de la distinction des biens considérés principalement par rapport au domaine public (Dijon, Victor Lagier, Libraire-Éditeur, 1834), IV.

Rascón García, César - García GonzÁlez, José María, Ley de las XII Tablas (Madrid, Tecnos, 1993).

Ricсовоno, Salvatore, Fontes Iuris Romani Antejustiniani, Pars Prima, Leges (Firenze, Barbèra, 1968).

Rivera Garretas, Milagros, El Fuero de Uclés (siglos XII-XIV), en AHDE., 52 (1982).

Roca Roca, Eduardo, La contaminación de las aguas públicas (sus problemas y régimen jurídico administrativo), en Revista General del Derecho, 336, 337-338 (octubrenoviembre 1972).

RodRÍGUEZ FERNÁNDEZ, Justiniano, Los fueros locales de la provincia de Zamora (Salamanca, Junta de Castilla y León, Consejería de Cultura y Bienestar Social, 1990).

RODRÍGUEZ, Justiniano, Los fueros del Reino de León (2 vols., León, ediciones leonesas, 1981).

SAn Isidoro, Etymologiarum (edición bilingüe de Oroz, J. y Marcos, M. A., 2a edición, Madrid, Biblioteca de autores cristianos, 1994).

Sargenti, Manlio, L'actio aquae pluviae arcendae. Contributo alla dottrina della responsabilità per danno nel diritto romano (Milano, Giuffrè, 1940). 
SitZIA, Francesco, Ricerche in tema di "actio aquae pluviae arcendae". Dalle XII Tavole all'epoca classica (Milano, Giuffrè, 1977).

SPRINGER, Allen L., The International Law of Pollution (Wesport-London, Quórum Books, 1983).

Vázquez de Parga, Luis, Fuero de Fuentes de la Alcarria, en AHDE., 18 (1947).

Vercher Noguera, Antonio, El derecho europeo medioambiental (Madrid, Consejo General del Poder Judicial, 2005).

Vercher Noguera, Antonio, El derecho europeo medioambiental: la protección del medio ambiente en la Unión Europea. Aspectos críticos (Madrid, Consejo General del Poder Judicial, 2008).

Zamora Manzano, José Luis, Precedentes romanos sobre el Derecho ambiental. La contaminación de las aguas, canalización de las aguas fecales y la tala ilícita forestal (Madrid, Edisofer, 2003). 

